This PDF is a selection from a published volume from the National Bureau of Economic Research

Volume Title: Economic and Financial Crises in Emerging Market Economies

Volume Author/Editor: Martin Feldstein, editor

Volume Publisher: University of Chicago Press

Volume ISBN: 0-226-24109-2

Volume URL: http://www.nber.org/books/feld03-1

Conference Date: October 19-21, 2000

Publication Date: January 2003

Title: IMF Stabilization Programs

Author: Anne O. Krueger, Stanley Fischer, Jeffrey D. Sachs

URL: http://www.nber.org/chapters/c9777 


\title{
IMF Stabilization Programs
}

\author{
1. Anne O. Krueger \\ 2. Stanley Fischer \\ 3. Jeffrey D. Sachs
}

\section{Anne O. Krueger}

\section{IMF Stabilization Programs}

The International Monetary Fund (IMF) was established after the Second World War at Bretton Woods (along with the International Bank for Reconstruction and Development, now referred to as the World Bank) as a multilateral institution to coordinate exchange rate arrangements among nations. The immediate concerns of the original IMF architects focused on avoiding the competitive devaluations of the 1930s, while at the same time encouraging liberalization of the world trading system. ${ }^{1}$ It was anticipated that there would be a worldwide system of "fixed, but adjustable" exchange rates, with adjustments coming only when there was "fundamental disequilibrium."2 In normal times, it was thought that there might be temporary financing problems for countries that could maintain their fixed exchange rates with the help of the IMF.

The preeminence of the American economy and the accompanying "dol-

The author is indebted to Jose Antonio Gonzalez, Nicholas Hope, Michael Michaely, T. N. Srinivasan, Jungho Yoo, and participants in the NBER Woodstock conference for helpful comments on the earlier draft of this paper, and to Marco Sorge for research assistance.

1. It was intended that there be an International Trade Organization (ITO) along with the IMF and World Bank. The ITO was to oversee trading arrangements. However, the ITO never came into being; instead of an international organization, the General Agreement on Tariffs and Trade (GATT) came into being by executive degree, and there was no international organization until the World Trade Organization (which incorporated the GATT) in 1995. For a brief history of the founding of the Bretton Woods institutions, see Krueger (1999).

2. The concept of "fundamental disequilibrium" was never well defined. In practice, most IMF stabilization programs have included an exchange rate adjustment. 
lar shortage" in the international economy immediately after the Second World War was not anticipated, and there emerged a de facto ("fixed but adjustable") dollar standard, although the dollar itself was pegged to gold. The IMF functioned much as expected in occasional balance-of-payments crises among developed countries, such as the pound devaluations of $1949^{3}$ and 1967 and the German appreciation of 1960. However, most Fund activity was with developing countries even in its initial decades, as the strength and resources of the American economy dwarfed those of the Fund, while the perceived needs for reconstruction support (which came in large part from the Marshall Plan) had been greatly underestimated.

Among the developing countries, balance-of-payments difficulties were sufficiently frequent that the Fund quickly came to be involved in several of these crises annually. During the 1950s and 1960s, the Fund dealt occasionally with developed countries' exchange rate or payments difficulties, but the bulk of its activities consisted of "stabilization programs" for developing countries. ${ }^{4}$

By 1973, the "Bretton Woods" system of fixed, but adjustable, exchange rates was abandoned, and the major developed countries adopted floating exchange rates. ${ }^{5}$ With that, IMF stabilization programs became centered almost entirely on individual developing countries. The basic content of these programs remained much the same over the years, and this is discussed first in section 4.1.1. A key feature of the international financial system, as it interacted with these crises and subsequent programs, was that the trigger for a crisis usually took the form of an inability to continue servicing debt voluntarily. Most of that debt was either short-term trade credits or owed to official creditors.

With the 1980s, the first major change in Fund stabilization programs took place. By that time, some of the countries confronting crises had very large volumes of debt, both short and long term, outstanding to private creditors. The Fund's resources were often small relative to the size of outstanding private indebtedness, and it changed the nature of the way in which the Fund could support countries in crisis. Throughout the 1980s, most of these countries still maintained fairly severe and stringent capital controls, and many maintained quantitative restrictions on imports. ${ }^{6}$

3. The French, however, undertook an early devaluation and notified the IMF only after they had done so.

4. See Sturc (1968) for a description and analysis of early Fund stabilization programs.

5. Among the industrial countries, Canada had earlier adopted a floating exchange rate, and the United States had cut its tie to gold in 1971

6. Many African countries were hard-hit by the debt crisis of the 1980s. Longer-term IMF programs (Extended Structural Adjustment Facilities) were established to support them. These programs differed in a number of ways from the programs discussed here, but their assessment would entail consideration of a number of different issues from those relevant to the Asian and other twin crises. At any event, the executive directors of the IMF voted in September 2000 to abolish these longer-term arrangements. 
By the 1990s, however, some of the rapidly growing developing countries had greatly liberalized their trade regimes and opened their capital accounts to a considerable extent. In some instances, when crises arose, domestic financial systems were severely affected in ways that will be examined later. This changed both the time frame in which crises could erupt and be addressed and the nature of the impact of crises on the domestic economy.

Although Mexico confronted a balance-of-payments-cum-financial crisis (twin crisis) late in 1994, most observers of the world economy were alerted to these new-style twin crises with the Asian financial crises of 199798. The magnitude of the crises and the severity of the impact on the crisisafflicted countries led many to question the role of the IMF both in failing to anticipate and prevent the difficulties and in overseeing programs intended to address the crisis situations.

The purpose of this paper is to examine the role of the IMF in the 1990s twin crises. Focus is on stabilization aspects of the program: Goldstein (2001) considers the extent to which these programs addressed areas other than those that were aimed at restoring viable financial and balance-ofpayments situations, and those issues are not covered here. The starting point is with the more traditional IMF stabilization programs of the 1960s and 1970s. That is the subject of section 4.1.1. In section 4.1.2, the analysis is extended to cover situations in which balance-of-payments crises are accompanied by financial crises. A third section then considers the sorts of programs that must be developed when the financial and exchange rate crises occur simultaneously.

On the basis of that analysis, two of the IMF programs effected in the Asian crisis - Korea's and Indonesia's - will be examined in section 4.1.4. Section 4.1.5 then draws on the experience under these programs and contrasts them with the behavior of some other crisis countries and countries not subject to crisis.

\subsubsection{Traditional Stabilization Programs}

Consider a small open economy, initially in equilibrium at a fixed exchange rate, that experiences domestic inflation at a rate more rapid than is occurring in the rest of the world. As the demand for foreign goods grows more rapidly than the supply of foreign exchange, ${ }^{7}$ there are several policy options. There is excess demand for foreign goods, so that the country initially incurs a current account deficit not offset by long-term capital in-

7. It is possible, of course, that favorable shifts in the terms of trade could offset the appreciation of the real exchange rate. However, this would be coincidence, and it is assumed here that there is no such offset. Without domestic inflation, the same excess demand for foreign exchange is likely to diminish as the demand for foreign exchange increases with an appreciating real exchange rate, because domestic demand for relatively cheaper exportables rises while the profitability of producing them falls. 
flows. ${ }^{8}$ In that event, the current account deficit can be financed in the short run by running down foreign exchange reserves or by borrowing from abroad. However, unless something else (such as the rate of inflation) changes, the deficit is unsustainable and some form of adjustment will be forced.

There are two alternatives if a fixed nominal exchange rate is to be maintained. A first is to let domestic monetary and fiscal policy be sufficiently deflationary so that domestic prices fall relative to those in the rest of the world (or fail to rise as rapidly as prices are rising in the rest of the world) or domestic incomes fall (and hence the domestic demand for foreign goods shifts downward while the domestic supply of exportables increases). The second alternative is to impose exchange controls, rationing the available foreign exchange through quantitative means across various demanders, and attempting to restrict foreign exchange usage to the available supply of foreign exchange. This can be achieved, at least to some degree, although over time private agents discover a number of ways in which to evade the regime. ${ }^{9}$

In the 1950s and 1960s, many developing countries chose to use quantitative restrictions (QRs) to keep their current account deficits from becoming larger than could be financed. These $\mathrm{QRs}$ were permitted on "balance of payments" grounds under General Agreement on Tariffs and Trade (GATT) rules. However, the costs of these QRs mounted over time, as export earnings failed to grow as rapidly as real gross domestic product (GDP; the real exchange rate was appreciating because the domestic inflation rate was greater than that in the rest of the world), while it was increasingly difficult to contain the growing excess demand for imports.

Even in the world of the 1950s and 1960s, a "crisis" eventually took place. ${ }^{10}$ In some countries, the crisis was triggered when the lack of imports began severely restricting economic activity. This was the case in Turkey, for example, in 1958 when the crops (which were a major source of export earnings) could not be harvested: for lack of petroleum imports, farmers were unable to use farm machinery to harvest crops or to transport them to

8. More generally, the current account deficit simply needs to exceed the volume of voluntary net capital inflows. Hence, if a country is a recipient of some foreign direct investment (FDI; or foreign aid, or portfolio investment) and no other capital inflows, the relevant "deficit" is the current account balance less the net FDI (or other voluntary flows). However, it simplifies the exposition to assume no voluntary capital flows so that the entire current account deficit somehow must be financed.

9. As excess demand for foreign exchange builds up under a fixed nominal exchange rate and exchange control, various forms of evasion spring up. These illegal flows (smuggling, false invoicing, etc.) generally result in large "errors and omissions" items in the balance-of-payments statistics of countries attempting to contain excess demand for foreign exchange as the real exchange rate appreciates to more and more unrealistic levels. One of the extreme instances was in Ghana in the early 1980s, when the black market exchange rate reached a level more than 900 percent above the official exchange rate.

10. For a good documentary history of the IMF, see James (1996). 
ports. ${ }^{11}$ In other instances, the unavailability of sufficient foreign exchange to maintain voluntary debt service signaled the onset of the crisis. This was the more frequent trigger for change in regime in some Latin American countries where accelerating inflation at a fixed (or insufficiently adjusted) nominal exchange rate led to rapidly rising demand for foreign goods and services, which the authorities attempted to satisfy (in an effort to reduce inflationary pressures) until financing sources dried up. Excess demand for foreign exchange - usually expansionary fiscal and monetary policy - also led to accelerating inflation, which finally reached unacceptable levels. In these circumstances, real exchange rates had appreciated greatly by the time the crisis point was reached.

Regardless of the triggering mechanism, the underlying problems were similar in origin: excess demand for goods and services had resulted from fiscal deficits and expansionary monetary policy. At the point when the authorities deemed the situations sufficiently severe to warrant action ${ }^{12}$ and approached the IMF, the usual situation was that current account expenditures exceeded current account revenues by a considerable margin (often with a large errors and omissions item in the balance of payments, as well, reflecting unrecorded outflows), the real exchange rate had appreciated substantially relative to other countries, the rate of inflation was unacceptably high, and all of these had been driven in large part by fiscal deficits. In many instances, there were capital outflows occurring through such mechanisms as underinvoicing of exports, overinvoicing of imports, inflated tourist expenses, and overstated factor payments abroad. Simultaneously, in anticipation of an exchange rate change, importers were attempting to accelerate imports and build up inventories, exporters were delaying exports, and so on. Despite capital controls, the number of devices people could find with which to speculate against a currency was remarkable. ${ }^{13}$

When the IMF was approached for support, the usual situation was one in which the problems mentioned above had to be addressed, and, in addition, the lack of imports was itself fueling inflation and restricting production. The term "stabilization" came about because these economies at times of balance-of-payments crisis were thought of as spiraling out of control, with inflation rising, efforts at capital flight intensifying, and debt-servicing difficulties mounting at increasing rates. ${ }^{14}$ The essential IMF stabilization program, therefore, usually consisted of an agreed-upon set of ceilings on

11. By 1958, Turkey had accumulated considerable short-term debt in the form of suppliers' credits and could not obtain even trade financing for imports. Hence, the inability to borrow further (and creditors' demands for repayments) was the proximate cause of the difficulty.

12. Defining a crisis is difficult. One country's crisis is another country's everyday occurrence. See Little, Cooper, Corden, and Rajapatirana (1993) for a discussion.

13. It was even reported that the London Times carried advertisements offering to overinvoice shipments to countries with exchange control and stating its percentage fee.

14. See Sturc (1968) for a description and analysis of some early Fund stabilization programs. 
fiscal deficits and domestic credit creation, ${ }^{15}$ and a change to a new, fixed, nominal exchange rate. ${ }^{16}$

The altered exchange rate very often immediately reversed the speculative capital outflow, so that the recorded balance-of-payments position could improve very quickly. The fiscal and monetary tightening associated with the fiscal and domestic credit ceilings usually resulted in a slowdown in the rate of economic activity and in the rate of inflation, which in turn reduced the excess demand for imports and freed up the supply of exports. All of these measures then served to generate balance-of-payments improvement. Whether the improvement was long-lasting depended on a number of factors, chief among which was whether the key sources of inflationary pressure and excess demand had been satisfactorily addressed. ${ }^{17}$

For future reference, it is worth pointing out that, in some instances, IMF programs even in the 1950s and 1960s often imposed conditions on governmental behavior. In some cases, price controls on state economic enterprises (SEEs) insured that those SEEs would incur losses, which in turn were financed by loans from the central bank. In cases in which these SEE deficits were important and increasing, it was recognized that there could be no reduction in the pressures of excess demand unless the underlying problem - the controls on prices that led to SEE losses and central bank credit creation - were removed. The same sort of conditions applied on occasion when particular subsidies - such as that for Egyptian grain ${ }^{18}$ - were so large that fiscal balance could not be achieved without reducing them. In the Dominican Republic in the early 1980s, the state-owned electric company was incurring a deficit equal to 11 percent of GDP! In that circumstance, it was evident that a major source of the fiscal deficit and inflationary pressure could not be removed until the underlying financial position of the electric company was addressed.

In addition to the circumstances in which changing a domestic policy was essential if the underlying factors that had led to crisis were not immediately to recur, there were cases in which a highly inefficient governmental policy could be replaced with a more rational one: such was the case with the Turk-

15. The independent ceiling on credit creation apparently was first initiated when IMF staff thought that there were off-budget expenditures being substituted for governmental expenditures.

16. For an assessment of IMF programs as of the late 1970s, before debts to private creditors had become important, see Cline and Weintraub (1981). Even at that time, there was considerable criticism of Fund stabilization programs. For some examples, see Williamson (1983).

17. See Edwards (1989) and Krueger (1978) for analyses of the paths of inflation, the real exchange rate, and current account balances after devaluations. It was not always true that economic contraction followed a fiscal or monetary tightening. Trade liberalization often permitted an expansion in the rate of economic activity. In Turkey in 1958, for example, real GDP expanded by 5 percent after the deflationary program of August 1958 was put into effect.

18. In the case of Egyptian grains, these were sold so cheaply in the domestic market that farmers found it profitable to feed bread to their chickens. Fund insistence on their reduction was followed by street riots, which led to a reimposition of the grain subsidies. 
ish devaluation of 1958, after which the earlier chaotic trade regime under which everyone queued for unpredictable lengths of time for import licenses was replaced by a system in which designated imports were granted licenses virtually automatically, whereas other imports were subject to licensing through which maximums were set as to the quantity that would be permitted to be imported.

Usually, by the time the IMF was approached, countries had run down their foreign exchange reserves to very low levels and were incurring or had incurred considerable debts as they attempted to maintain imports and economic growth in the face of an increasingly overvalued exchange rate and worsening balance-of-payments position. Moreover, as already mentioned, imports had sometimes been greatly suppressed prior to the inauguration of the IMF program. For either or both of these reasons, governments typically sought debt rescheduling and IMF financing. Debt rescheduling spread out the overhang of debt to a more feasible repayment schedule. Typically, official debt (which was often the major portion of long-term financing) was rescheduled through a meeting of official creditors organized by the IMF but de jure carried out under the auspices of the French Treasury, and known as the Paris Club. Private debts - usually short-term credits from commercial banks - were rescheduled at a meeting of private creditors usually held in London and known as the London Club.

Often, countries' import flows had been severely restricted or reduced immediately preceding the crisis, while foreign exchange earnings had fallen sharply. In order to "restart" the economy, it was not sufficient to reschedule debt: new money was needed, and IMF financing was extended. ${ }^{19}$ In many cases, IMF financing was supplemented by official credits from the World Bank and bilateral donors. This financing, at a minimum, enabled an inflow of imports which itself was deflationary and often also permitted a reduction in the restrictiveness of the $\mathrm{QR}$ regime for imports.

The mechanism by which the IMF program was adopted was straightforward. Once it was deemed that a proposed program was satisfactory, the head of government would sign a letter of intent (LOI) to the managing director of the IMF, requesting IMF financing and laying forth the govern-

19. Under the Articles of Agreement of the IMF, countries are entitled to draw down a certain amount from the IMF automatically. The more they have drawn down, the stricter are the criteria for drawing down further tranches. In most instances, countries embarking upon stabilization programs had already drawn down a considerable amount and were seeking higher tranches of lending. The Fund did not provide all financing at once; stabilization programs were usually for two years, and a typical program set six-month targets. At the end of each sixmonth period, fund staff reviewed performance under the program, and a next tranche was released when performance was deemed adequate. Evaluating performance was in some regards problematic: when countries fell short of some targets, issues arose as to whether the shortfall was the result of circumstances unforeseen at the time of the program negotiation and whether the shortfall was serious enough to warrant suspension of the program. There were frequent program suspensions, but also frequent compromises, and many instances in which governments simply did not abide by the terms of the program. 
ment's plans as to the key macroeconomic indicators. Almost always, it was agreed that there would be a change in the nominal exchange rate, or in the exchange rate regime, as part of the program. Likewise, ceilings on fiscal deficits and domestic credit were almost always included. Proposed changes in other key parameters (such as the subsidy rate for Egyptian grain or the pricing of Dominican electricity) were also spelled out.

In some cases, the program had already been adopted in the borrowing country. This was the case in Turkey in 1980, for example, when the domestic authorities undertook sweeping reforms (which went far beyond what the Fund would have required in order to extend financial support) and then approached the Fund for a loan. In other cases, the program was devised jointly by IMF staff and government officials. ${ }^{20}$ Often, this was because policymakers in the would-be borrower country were reluctant to alter policies; however, in the absence of any alteration, it was clear that Fund support would do no more than provide temporary breathing space and only postpone the onset of a similar crisis. And it is self-evident that it would do a disservice to a country to lend in support of a futile program: the outcome would be a renewed crisis at a later date, with more debt having accumulated because of the first program. However, since a program in most instances increased the probability that economic performance would improve, some programs were no doubt undertaken where chances of success were very limited.

The "joint" determination of the program was really an outcome of a negotiating effort between IMF officials and representatives of the government. Devising any stabilization program inevitably entailed judgment. Macroeconomic outcomes are uncertain: unforeseen or unpredictable future events (such as the prices of key exportable commodities or the weather), unpredictable or unanticipated (in terms of timing as well as of magnitude) responses of consumers and producers to altered relative prices, serious strikes, and changes in the government can all affect the speed of response. A "stronger" program carries a higher probability of success, but even a weak program could succeed with good fortune in terms of weather, external terms of trade changes, and appropriate changes in expectations and consumer and producer behavior. ${ }^{21}$

Moreover, a strong program is likely to entail more short-run adjustment

20. It is often forgotten that, in most developing countries especially in the 1950s and 1960s, the pool of available talent in key government ministries was very thin. Quite aside from the lessons of experience and changed economic thinking, one reason why developing countries' economic policies have been gradually becoming less inchoate over time has been the increased quality and breadth of able civil servants and policymakers.

21. It is probably true that consumer and producer responses are weaker and slower in countries where there is a history of past failed attempted stabilization programs. Since that variable is different for each country, to the extent that past history matters, it is clear that there is no "one size fits all" model of how much adjustment in the key variables is warranted. Moreover, since the outcome is in any event probabilistic, a key question concerns the probability of success that IMF and government officials should accept for programs, bearing in mind that "stronger" programs (with larger exchange rate changes and sharper tightening of monetary and fiscal policies) probably bring larger adjustment costs to politically vocal sections of society. 
costs. ${ }^{22}$ A cut of $x$ percent in the fiscal deficit entails a larger increase in tax receipts or a greater reduction in government expenditures than a smaller percentage cut. Likewise, a larger increase in tariffs for electricity, bus fares, or other governmental services imposes more of a hardship on users than does a smaller increase.

Hence, there is reason to adopt no stronger a program than is deemed warranted in order to stabilize the economy and provide a sufficiently high probability that growth can be resumed. However, the fact that larger macroeconomic policy changes may impose hardships on particular groups in the economy is often used to oppose any changes at all. Hardships endured after the start of a Fund program are generally blamed on the program, without regard to the counterfactual trajectory of economic variables that would have occurred had there been no Fund program and the economy continued its downward spiral. Space does not permit a review of the evidence in this regard, but it is increasingly apparent that the very groups that are alleged to be most harmed by IMF stabilization programs are the groups that are most harmed by the unstable macroeconomic environment (especially inflation) that is generally the alternative.

However, in most instances, it could be expected that Fund programs with any credibility whatsoever would be followed by short-term increases in foreign exchange receipts and reductions in demand for foreign exchange. This is because these programs were usually adopted at a time when speculation against the currency had occurred and, with it, speculative withholding of exports, speculative prepayment of imports, and capital flight through whatever means were available. Thus, in the period immediately following the announcement of a Fund program and an associated devaluation, the foreign exchange situation could be expected to improve (both because of the reversal of speculative outflows anticipating the devaluation and because the receipt of Fund resources provided assurance in most instances that further exchange rate changes would not take place in the near future), and hence the crisis that brought the government to the Fund in the first place had passed and pressures to conform with the agreed-upon program were therefore much smaller.

22. There are two dimensions of "strong" and "weak." On one hand, there is the magnitude of the fiscal, monetary, exchange rate, and other adjustments. On the other hand, there is a question as to the period of time during which these adjustments are phased in. There is increasing, but by no means conclusive, evidence that changes in the key macroeconomic variables that are carried out quickly have smaller costs than those that are phased in over a longer time period, for a variety of reasons. First, a rapid change in macroeconomic signals sends a message that policymakers are serious in their determination to restore macroeconomic equilibrium. Second, those sectors of the economy (exportables, in particular) which benefit from reforms are likely to respond more rapidly when the adjustment is made at once than when it is phased in over time. Third, the political opposition faces a higher hurdle in its efforts to oppose and overturn reforms that have already been achieved than it does for those that are merely announced as intended at a future date. The above discussion, therefore, refers to the magnitude of the altered policies, not the speed. It should be noted, however, that some changes - such as in government expenditures or in tax structures - inevitably require time. 
For this reason, there was obvious cause for concern that countries, once having received financial support and experienced a much-relaxed current account situation, would revert to their fiscal and monetary habits that had brought on the crisis in the first place. To avoid this, the Fund's programs typically imposed "conditionality," and Fund resources were extended only after staff reviewed the key macroeconomic performance indicators agreed upon. Thus, there was not a single domestic credit ceiling: there were ceilings specified for each six-month or one-year interval for the life of the program. Fiscal performance was also specified for a sequence of periods.

What this led to was the release of a tranche of funding once a Fund program was initially announced, with specified future dates at which further tranches would be released, assuming the country met its targets set forth in the LOI. It often happened that, on review for release of a later tranche, targets would not have been met. As already indicated, anticipating macroeconomic events is not a precise science, and the task of the IMF staff in the review was threefold: (a) to ascertain the extent to which the failure to meet targets threatened the success of the program; (b) to determine the extent to which failures to meet targets were a result of unanticipated macroeconomic shocks, of misestimation of the economy's response to the program, or, instead, of failure to implement the program; and (c) renegotiate targets for subsequent tranches in light of the findings with respect to the first two questions. When the failure to meet targets was the consequence of internal policy, the task was to ascertain whether it was feasible to get the program back to a place where there was a realistic chance of success, or whether to abandon the program.

Evidently, judgment had to be used. The first question - whether the failure to meet targets was of sufficient magnitude and likely duration ${ }^{23}$-is often a judgment call. Even when the cause of failure is clearly external (as, for example, an unanticipated increase in the price of oil leading to a larger fiscal and current account deficit than in the program), changes in targets may be warranted. Even when the cause of failure is governmental inaction (as happens, for example, when tax reforms are turned down by Parliament), a question is whether sufficient action could and would be taken in the immediate future to get the program back on track.

Needless to say, a number of fund programs have been canceled, and many others have had targets renegotiated. ${ }^{24}$ Even in the initial program, it is always a difficult judgment call as to how much fiscal and monetary tightening and how much exchange rate change is the minimum that would have

23. Sometimes, unanticipated delays in fiscal expenditure reductions or increased tax receipts can occur that would be serious if sustained, but for which there is evidence that the delay was once and for all. And, of course, if the fiscal target is a deficit reduction of, say, 1 percent of GDP over a six-month period, there is a question as to whether 0.99 percent of GDP, 0.9 percent of GDP, 0.8 percent of GDP reduction, or some other number is sufficiently close as to warrant continuing support.

24. See Ergin (1999) for data on the number of cancellations and renegotiations over the years. 
a significant chance for successful outcomes. There is also a question as to the ability and willingness of the relevant government officials in the program country to undertake the agreed-upon policies. Once the program is under way, information on terms of trade, weather, and other variables removes some uncertainties but increases others.

In fact, many IMF programs have failed to reverse the underlying economic trends. ${ }^{25}$ Especially in the 1960s and 1970s, a typical experience was the "stop-go" cycle, in which the inauguration of a Fund program marked a period during which the government fiscal deficit and the rate of domestic credit creation were reduced, while the depreciated real exchange rate induced a reduced quantity demanded of imports and an increased flow of exports. These usually resulted in some degree of domestic recession (depending on whether the expansionary effects of import liberalization with the associated greater availability of intermediate goods and raw materials and of greater exports offset the contractionary effects of tighter monetary and fiscal policy). That, in turn, released further goods into export channels and reduced the demand for imports. Simultaneously, reduced domestic demand usually more than offset other effects, to result in - at least temporarily - a reduction in the rate of inflation.

However, once these effects had been taking hold for some time, governments typically began to increase expenditures and ease the monetary situation. As that happened, the real exchange rate began appreciating, ${ }^{26}$ and, with it, the incipient current account deficit once again began increasing. Inflationary pressure accelerated, and, with it, the boom component of the cycle was once again under way. The boom ended when the next exchange rate or debt-servicing crisis became too costly, and once again the IMF was approached. This was referred to as developing countries' "stop-go" cycles.

Hence, even before 1973 and the first oil price increase, ${ }^{27}$ a number of countries had had multiple IMF programs. ${ }^{28}$ In some instances, they were

25. See Krueger (1978) for an early tabulation of the real exchange rates prevailing one, two, and three years after devaluations in ten developing countries in the $1950 \mathrm{~s}, 1960 \mathrm{~s}$, and early 1970s. See Edwards (1989) for a review of the experience with a much larger number of countries over the 1970s and 1980s.

26. The index of dollar prices of tradable goods was virtually constant over the period from 1952 to 1969 . As a consequence, any country with even a 5 percent rate of domestic inflation at a fixed exchange rate experienced real appreciation of its currency. Many developing countries had average inflation rates well in excess of that number, although the average rate of inflation across countries rose markedly after 1973.

27. After 1973, most developing countries continued to maintain fixed nominal exchange rates, or crawling pegs, which could lead to problems if the terms of trade deteriorated sharply. For this reason, they continued to call upon the IMF for support even after the industrialized countries' abandonment of fixed exchange rates had markedly diminished the fund's role with respect to their economies.

28. It is sometimes argued that finance ministers and other economic policymakers know that the IMF will support a program and that they therefore accept more risk than they would in the absence of the IMF. However, there is ample evidence that economic policy officials, and especially central bankers, who are in office at times of crisis quickly lose their jobs. See Cooper (1971). 
almost continuous; in others, several years separated the resort to Fund support. In Chile, for example, there were Fund programs in 1956, 1959, and 1965 even prior to the inflation expansion set off under President Allende and the massive adjustment of the mid-1970s (see Behrman 1976). There were Fund programs in Turkey in 1958, 1970, and 1977, prior to the Turkish reforms of 1980. During the latter half of the 1970s, there were repeated renegotiations and abandonments of programs.

Before turning to the role of financial transactions in these crises and responses, I need to stress two final points. First, until the 1980s, the majority of developing countries used fixed nominal exchange rate regimes, so that a devaluation was an important part of their stabilization programs. Inappropriate real exchange rates led to retarded growth or depressed export earnings, increased imports or increasingly restrictive import licensing, depressed capital inflows, and encouraged various forms of illegal transactions to enable capital flight. By the 1970s, some of these costs were being recognized, and a few developing countries began experimenting with alternative exchange rate regimes. A few countries permitted their exchange rate to float during the crisis or in a period immediately afterward, prior to fixing a new nominal exchange rate. Some others, most notably Colombia and Brazil, began using a crawling peg exchange rate regime, under which the nominal exchange rate was altered at relatively frequent intervals according to a formula under which the adjustment was sufficient to compensate between the rate of inflation in the country in question and the average rate in its major trading partners.

The second point is that, although exchange controls certainly restricted the free flow of capital, and private capital flows were relatively small contrasted with official flows or their magnitudes in the 1990s, businesses and individuals found plenty of ways to evade exchange controls, and capital flight was often the trigger for a balance-of-payments crisis. Capital flight may be easier and more sensitive to small changes in macroeconomic magnitudes in the 1990s than it was in earlier decades, but it is not new.

\subsubsection{Financial Crises}

There have been a number of episodes of financial crisis with minimal balance-of-payments involvement over the years. The United States had many such crises in the nineteenth century, a major motive for establishing the Federal Reserve System. Sweden had a major financial crisis in 1992, which was again largely national and financial in origin, although the crown was also attacked (the overnight interest rate rose to an annual rate of over 400 percent at the peak of the crisis). And, of course, Japan's difficulties in the 1990s have had a weak banking system as a major underlying factor. Even the American savings and loan problem of the early 1980s represented a financial crisis, although it was relatively small scale contrasted with many 
others, ${ }^{29}$ as measured by the percentage of the overall financial system affected or by the percentage of GDP of the ultimate bailout cost.

Because it has primarily been the banks that have been involved in the twin crises of the 1990s, I shall speak of banks as if they were the only important financial institution. Clearly, they are not, but since they are central and were major for the crises of concern here, it will simplify the exposition to refer to the "banks" rather than to "financial-sector institutions."

The business of financial intermediation is important for development and economic growth, because intermediation enables the resources savers make available for investment to be allocated to their best uses. By its nature, the finding of those best uses requires a skilled assessment of the likely future outcome of any given venture. That outcome is determined by several things: (a) the ability of the borrower; (b) the prospect that the proposed venture is technically feasible at a cost such that there will be sufficient demand in the market to make it pay; and (c) that the external environment does not change in ways that negatively impact the venture. All three of these components are better judged by trained professionals than others, but each of them is nonetheless subject to uncertainty.

Even the best of bank lending officers does not have a perfect record of forecasting which would-be borrowers will be successful and enabled to service their loans. In some instances, the debtor's plans simply do not work; in others, unforeseen circumstances (a deep recession, changing consumer tastes, development by a competitor of a superior substitute) can lead to the failure of a venture to yield a sufficient cash flow to enable debt servicing.

All banks have, and should have, ${ }^{30}$ some nonperforming loans (NPLs) and reserves against NPLs. Moreover, since banks charge a higher interest rate on riskier loans, mechanisms must be devised to provide incentives and an environment in which bankers manage risk appropriately. If, for example, the owner of a bank has none of his own capital invested in it, he has nothing to lose if risky loans fail, and he will therefore have an incentive to have too risky a portfolio. It is for this reason that capital adequacy requirements are a part of reasonable banking regulation.

When the fraction of NPLs (recorded or not) increases, banks must charge higher interest rates on the rest of their portfolio to cover their costs and be profitable than would be the case with a smaller fraction of NPLs. In the extreme case when there are no performing loans, a bank's capacities to lend are entirely destroyed, but in fact that occurs long before NPLs absorb the entire portfolio.

Because of this, a bank that experiences above-average difficulty with its

29. It is not clear whether the savings and loan problem would have remained "small-scale" if it had not been handled reasonably quickly. One of the characteristics of weak financial institutions is that there is a tendency for problems to spread.

30. If a bank had no nonperforming loans (NPLs) on its books, it would either have been far too conservative in its lending policies or it would be failing to write down bad loans. 
loan portfolio is highly vulnerable, because potential "sound" borrowers will be able to borrow at lower cost from other banks, leaving only riskier borrowers approaching the troubled bank, and depositors may attempt to shift their funds as information about the financial health of the institution becomes known. This, in turn, lowers the bank's reserve ratio. As these things happen, the fraction of NPLs is likely to rise still further.

When a number of banks experience an increasing fraction of NPLs simultaneously, the failure of any one or several of them results in losses to the depositors and shareholders. Those losses, in turn, weaken their asset position and can impair the ability of some of that group to service their obligations. As that happens, there is further weakening of the balance sheets. At some point, depositors recognize the danger to the banks and begin attempting to withdraw their funds, thus leading to the banking crisis. If banks are forced to refuse repayment, those depositors in turn become further handicapped in servicing their obligations, and, in addition, panic is likely to ensue.

When the banking system is so weak (i.e., when it has such a high fraction of NPLs in its portfolio) or is indeed under attack by depositors who have lost confidence in it, there are major risks in failure of the government to act. In particular, as individual financial institutions become unable to meet the demands for withdrawals, the liquidity of depositors falls, they fall behind or further behind on their debt-servicing obligations, and a downward spiral can occur in the absence of action.

To restore the banking system to economic health requires a number of measures. A first is to restore the banks' balance sheets. That may entail removing the bad paper from the banks, or it may entail forcing some healthy banks to consolidate with some that are impaired, or it may involve the government's acquiring the NPLs from the banks' portfolios in exchange for other assets. ${ }^{31}$ Achieving that is difficult for a number of reasons: (a) resources must be raised, usually from taxpayers, to bail out the banks, which is inherently unpopular; (b) major questions arise and must be addressed regarding the valuation to be placed on NPLs; (c) without careful attention, borrowers who could repay a fraction, but not all, of their debt will have no incentives to repay at all, and hence the fraction of NPLs and associated losses is likely to rise; and (d) when businesses are heavily indebted to banks, restructuring the individual firms' finances and indeed replacing debt with equity in their portfolios may be an essential part of the workout process. As will be seen below, this has certainly been true in Korea.

31. As will be seen below, in Indonesia, the government bought up the bad paper in the banking system, giving the banks nonnegotiable treasury bills in exchange for these NPLs. Since nonnegotiable bills cannot be lent, there was little new credit available in the Indonesian banking system. That being the case, even borrowers who could have serviced their bank debts ceased doing so, knowing that if they repaid their loans, they would not receive new credits. This is one major reason why the recovery of the Indonesian economy is so slow. 
Hence, "restoring banks' portfolios" is not a single activity. It requires valuation of the individual items in banks' portfolios, itself a lengthy process, as well as the development of arrangements for partially creditworthy borrowers to refinance their obligations. Further, it requires the development of incentives for banks to change their pattern of behavior, usually by raising capital adequacy standards and perhaps reevaluating the risk characteristics of various lending categories. ${ }^{32}$ However, this latter procedure is tricky, especially at a time of financial crisis, when there are few potential domestic lenders. ${ }^{33}$ Moreover, if foreign banks that do have the equity are permitted entry before the domestic banking system is restored to health, the fact that the new entrants are not carrying a significant fraction of NPLs on their books means that they can lend at a lower rate than the domestic banks to achieve the same profitability. If instead governments attempt to have healthy banks absorb less healthy ones, they must also insure equitable treatment for shareholders of the healthy banks, ensure that the newly merged banks are financially sound, and be willing to close banks with highly impaired balance sheets.

However, a government that undertook these actions and did nothing else would be failing to take any measures to prevent a recurrence of a banking crisis. If, for example, the weakness of the banking system came about because banks accepted too much risk, there is little point in restoring the banks' balance sheets without attempting to reduce the probability that they will once again develop an overly risky portfolio. ${ }^{34}$ Hence comes the need for strengthening capital adequacy requirements and also, usually, for strengthening prudential supervision.

Strengthening prudential supervision requires both changes in the regulatory framework and improved capabilities of the regulatory authorities. Although changing the regulatory framework may meet political opposition (on behalf of those benefiting from the prior status of the banks), it is relatively simple to accomplish. However, strengthening prudential supervision requires more resources in the regulatory offices, and those resources

32. One of the precrisis "distortions" in the global financial system at the time of the Asian financial crisis was that the Bank for International Settlements capital adequacy standards assigned a lower risk category to short-term than to long-term lending, thus encouraging a shorter-term structure of debt than would otherwise have occurred. Since the focus here is on IMF programs, however, that issue is outside the scope of this paper.

33. Failure to achieve capital adequacy appears to have been a significant contributor to the difficulties the Mexican government faced over the refinancing of the banks. The private owners of banks, it is said, had to a considerable degree acquired the funds to purchase their banks by borrowing from each other! Thus, although there were individual "owners" of banks, these "owners" were in fact in debt to other banks and had little to lose if their banks went bankrupt.

34. There is considerable evidence that the banks were extending credit to risky endeavors in the years leading up to the Asian financial crises and in Mexico prior to the 1994 crisis. Rates of increase of domestic credit, and the increment of domestic credit as a percentage of GDP, were very high - going to over 20 percent annually in Indonesia (contrasted with domestic credit expansion of less than 3 percent of GDP per year in industrialized countries). 
include trained bank examiners. Increasing the pool of qualified individuals is usually a drawn-out process.

Relating these considerations to developing countries, and to the financial crises of the 1990s, requires a step back to consider the role of banks in those countries. The importance of banks relative to the entire financial intermediation industry in developing countries is much greater than it is in wealthier countries. At very early stages of development, banks are virtually the only source of finance for enterprises with profitable investments they wish to pursue..$^{35}$ At that stage, most developing countries controlled the banks, imposing a ceiling both on the lending rate and on the deposit rate well below that that would have prevailed in a well-functioning financial market. For developing countries with appropriate policies, there were many profitable investment opportunities and consequent large excess demand for loans at the regulated rates. Governments typically oversaw credit rationing, requiring banks to give priority to particular activities at the expense of others. ${ }^{36}$ For example, in Korea in the early years after the opening up of the economy and the encouragement of exports, banks were instructed to lend to exporters at preferential interest rates. ${ }^{37}$ In other countries, credit to small farmers, to small businesses, or to other favored groups has been rationed at below-market interest rates. In other countries, however, preferential credit was directed to cronies or to politically influential individuals or groups.

When credit rationing prevails, the task of bank lending officers is simplified. In circumstances such as those that prevailed in Korea in the 1960s, almost any investment was bound to have a payoff in excess of the bank lending rate: Concerns with the creditworthiness of individual borrowers were very few, because the spectacular rate of economic growth (13 percent annual average) insured that almost anything would be profitable. The need for prudential supervision is much weaker than when there are competitive banking systems and market-determined lending practices, because banks under credit rationing are not really competing with each other but in effect

35. Almost by definition, the citizens of a poor country at the early stages of development have accumulated very little equity, and the ratio of bank loans outstanding to the value of capital stock, especially in the business sector, is very high. As development proceeds, that ratio can be expected to decline, but for countries that began rapid development within the past several decades, it is still well below that in industrial countries' markets.

36. In the 1960s, for example, the government of Korea regulated interest rates and directed credit allocations. The estimated real rate of interest on Korea Development Bank Loans in the period from 1962 to 1966 , for example, ranged from -0.8 percent to -26 percent. During the rest of the decade, the real rate of interest was positive, but never exceeded 6.1 percent. By contrast, estimated real rates of return on investment ranged from 20 to 35 percent. The curb, or informal, market rate of interest for those seeking additional funding was well over 40 percent throughout the decade, whereas the nominal rate of interest on bank lending never reached 30 percent. See Hong (1981).

37. It is important to note that all exporters were entitled to preferential credit, which was allocated according to formulas based only on export performance. There was no commodityspecific differentiation among exports. 
have a governmentally imposed monopoly. In those circumstances, to the extent that the interest rate is suppressed and banks have any choice among would-be borrowers, they naturally choose to lend to the safest borrowers, who will in effect be receiving a subsidy when they get loans at belowmarket interest rates. ${ }^{38}$

When a financial crisis occurs, the age-old prescription is to ease monetary policy generally and then for the central bank to follow the advice of Bagehot: lend freely at high interest rates to borrowers with good collateral. The point of this policy prescription is that healthy banks (or other financial institutions) that are illiquid because of the financial crisis need to be sorted out from those that are unhealthy and those that are (and would be even in the absence of crisis) insolvent. Simultaneously, a relatively easy money policy reduces the debt-servicing burden for borrowers, so that at the margin there are fewer NPLs. Indeed, a quick, but not necessarily desirable, way out of a financial crisis would be to inflate, especially if most loans have been made at fixed nominal interest rates. Inflation would ease the debt-servicing burden, although its other effects can have negative consequences and outweigh the benefits of reduced debt-servicing obligations.

\subsubsection{Twin Crises}

An economy afflicted with either a balance-of-payments crisis or a financial crisis presents the policymaker with serious challenges. To confront a balance-of-payments crisis, the appropriate policy responses entail an exchange rate change, tightening of monetary policy, and tightened fiscal policy. These measures, in turn, may require other supporting policy actions. To stem a financial crisis, by contrast, entails loosening of monetary policy, maintenance (or even appreciation) of the nominal exchange rate, and financial restructuring. Moreover, as is further elaborated below, an exchange rate adjustment as part of the response to a balance-of-payments or debt-servicing crisis can trigger a sufficient impairment of bank balance sheets to precipitate a simultaneous financial crisis. To a significant degree, in the presence of twin crises, whatever is done to address one will, in the short run, make the other worse.

In this section, I first address potential components of the policy package and their role, and later I address issues of sequencing and trade-offs across potential policy actions.

38. In some developing countries where import-substitution policies were followed, banks were directed to lend to them. Although they were often economically unsound, the firms producing import-substituting goods typically held sheltered and profitable positions in the domestic market and hence were financially profitable. However, in countries where much lending is directed toward "cronies" who have little intention to repay, a financial crisis can result from these practices. 


\section{Policies to Meet a Balance-of-Payments Crisis}

\section{Exchange Rate Change}

An exchange rate change is necessary once foreign exchange reserves are being depleted in circumstances in which the prevailing real exchange rate is unrealistic. As has already been seen, when policymakers have chosen a fixed nominal exchange rate regime ${ }^{39}$ and inflation rates have exceeded those in the rest of the world, the real appreciation of the currency gives speculators a one-sided bet: they can be reasonably confident that the currency will not appreciate in nominal terms, so they cannot lose (except for any forgone interest on holding foreign exchange relative to domestic currency), and they will gain in the event that there is a devaluation. In these circumstances, once capital outflows start increasing, there comes a point when only an exchange rate change of sufficient magnitude can deter further outflows.

The policymaker can choose to let the rate float or to announce and support a new, but more depreciated, fixed exchange rate. Three points need to be noted. A first one is that it is almost always domestic residents (who are closer to the scene and thus better informed) who are first to attempt to get out of local currency. Second, as already noted, there are many ways for domestic residents to move into foreign currency even under degrees of capital inconvertibility. Thus, it is not only the failure of foreign creditors to roll over loans or extend new financing that can place pressure on the foreign exchange rate; much of the domestic money supply can also do so.

Second, an exchange rate alteration may be inadequate to calm the markets. Indeed, there are numerous instances in which the announcement of a new exchange rate has not reduced pressures: this happened in Mexico after the initial devaluation in December $1994 .{ }^{40}$ Even a devalued exchange rate may be deemed "inappropriate" by market participants. For that reason, many policymakers have chosen to let their exchange rate float, at least in the immediate aftermath of a currency crisis. In that way, speculators face a two-way bet, and the exchange rate is market determined..$^{41}$ When foreign exchange reserves are minimal, and no additional resources are available from other sources, there is no option but to float the exchange rate.

39. A crawling peg regime was also susceptible to speculative pressures when circumstances should have led to a change in the real exchange rate. Such was the case in Brazil on several occasions when Brazil had a crawling peg exchange rate policy. These exchange rate changes were referred to as "maxi-devaluations" to distinguish them from the ongoing adjustments to maintain purchasing power parity.

40. For a chronology of events immediately prior to, during, and after the crisis, see IMF (1995, 53-79).

41. There is another advantage to floating the exchange rate: during the period in which a fixed exchange rate is defended, the foreign exchange authority (usually the central bank) is usually selling foreign exchange at the old exchange rate; if success of the currency is unsuccessful, foreign exchange reserves are built up at the new, depreciated exchange rate. Consequently, a central bank can incur large losses in an unsuccessful defense of the exchange rate. Floating the rate guarantees that there will not be large central bank losses. 
Third, although it is impossible to assert that there could never be a foreign exchange crisis under a floating exchange rate system, the probability of such a crisis is considerably reduced relative to that incurred under a fixed exchange rate when domestic monetary and fiscal policy are not targeted to the dictates of maintaining that rate. ${ }^{42}$ Moreover, as will be argued shortly, a floating exchange rate regime would be less likely to have significant foreign currency-denominated unhedged debts and therefore would be considerably less vulnerable to a twin crisis.

\section{Tightening Monetary Policy}

People move out of domestic currency into foreign currency because they expect a higher (risk-adjusted) return on holding foreign exchange than on holding domestic currency. As domestic interest rates rise, the cost of moving into foreign currency rises. Indeed, when the interest rate is high enough and the time horizon in which devaluation might occur is long enough, the costs to investors of holding lower-yielding foreign assets can be made sufficiently high to induce them to hold (high-interest-yielding, short-term) domestic assets. Hence, a higher domestic interest rate deters - at least at the margin - investors from moving out of assets denominated in domestic currency into foreign currency.

Thus, the conventional prescription for a balance-of-payments crisis is to tighten monetary policy, in order to make holding of domestic assets more attractive. This must, of course, be part of a package including an exchange rate change, because if an exchange rate change is thought to be imminent, there is no realistic possibility of attracting foreign funds. Even if the expected devaluation were only 10 percent and were anticipated with a high probability to occur within a week, that would require an overnight rate of interest equivalent to an annual rate of over 50,000 percent plus the return on the foreign asset to equate the expected returns and hence leave investors indifferent between domestic and foreign assets. Obviously, such a rate would bring all domestic transactions to a virtual halt. ${ }^{43}$

42. The crisis would manifest itself differently, however: the government in a country with large debts denominated in foreign currency might find itself unwilling or unable to raise sufficient tax revenue to purchase foreign exchange in the market, thereby triggering heightened inflationary pressures in its efforts to repay debt. Moreover, the debt-servicing burden might be sufficiently large that a depreciating exchange rate resulted in a larger fiscal deficit, which in turn would lead to a higher rate of inflation. The need for macroeconomic stabilization would be every bit as great as in the crises of the 1990s, but it is likely that the magnitude of the debtservicing obligations, relative to GDP and exports, would have to be considerably larger than it was in the countries experiencing twin crises in the 1990s.

43. In the 1950 s and the 1960 s when Chile confronted a balance-of-payments crisis, the authorities used to impose a 10,000 percent "guarantee deposit requirement." This was the amount of money, expressed as a percentage of the import cost plus insurance and freight price, that the would-be importer had to deposit, interest free (in the context of a three-digit annual rate of inflation) at the time of placing his order for foreign goods. The deposit would be returned after the goods had cleared customs. Because the lag between order and delivery in Chile was typically six months or longer, this was equivalent to a tax of many times the import cost of the good. Not surprisingly, imports ceased when the guarantee deposit requirement was imposed. 


\section{Adjusting Fiscal Policy}

In order to avoid accelerating and finally hyperinflation, of course, fiscal deficits have to be held under control. In many developing countries, these deficits are large enough that the monetary authorities are virtually forced to buy up new issues of government debt and maintain relatively easy monetary policy in order that the burden of the domestic debt-service obligations not become so large that that becomes destabilizing. Hence, tightening fiscal policy so that government domestic debt will not increase-or at least not by more than can be financed - is also a necessary part of any stabilization program. ${ }^{44}$

Of course, the higher the ratio of government domestic debt to GDP, the more costly it is to the government to have increased interest rates. When interest rates rise by 10 percentage points or more, the increased financing needs of a government with outstanding debt equal to 50 percent of GDP are equivalent to 5 percent or more of GDP. Raising such a large additional sum without triggering inflation is exceptionally difficult. Hence, the degree to which monetary policy can be tightened is partly a function of the relative size of government debt. For that reason, the increase in domestic interest rates automatically increases the prospective fiscal deficit because interest-carrying costs of the debt will increase. Since it is also likely that economic activity will slow, tax collections are likely to be somewhat below prior estimates, whereas fiscal expenditures may — unless adjusted-be higher. As a result, some fiscal tightening is called for, even in the event that the fiscal situation going into the crisis was reasonably balanced.

Thus, the ideal combination of exchange rate adjustment, fiscal curtailment, and monetary tightening depends heavily on the relative magnitudes of foreign currency-denominated and domestic government debt at the time of crisis. A country with little internal and much external debt would find the increased fiscal cost lower with relatively tighter monetary policy and less exchange rate adjustment (because more devaluation means a higher localcurrency cost of debt service); a country with a large domestic debt and few foreign currency-denominated obligations would find a package with a larger exchange rate adjustment and a smaller degree of monetary tightening to raise debt-servicing charges by a smaller amount more attractive. ${ }^{45}$

\section{Policies to Meet a Financial Crisis}

Just as quelling a balance-of-payments crisis requires restoration of the belief that the exchange rate is sustainable, or at least that the odds are even

44. It is also necessary because it is essential that expectations be altered. In the absence of fiscal tightening, the credibility of the stabilization program is at risk.

45. A strong case can be made that expansion of domestic credit under a fixed exchange rate regime is equivalent to increasing the contingent liabilities of the government, since the government is in fact implicitly guaranteeing that it will buy domestic currency at a specified rate. 
as to whether it will appreciate or depreciate, a financial crisis requires restoration of confidence in the financial system. However, there is no "quick fix," parallel to floating or altering the exchange rate, that can achieve that result.

The measures mentioned in section 4.1.2 - getting the bad paper out of the banking system while restructuring the debt of those who can pay part of their obligations, recapitalizing the banks, and providing incentives to avoid a repeat of the financial system's difficulties - all take time. Moreover, each one of these activities is contentious. Often, corporate restructuring to reduce the burden of debt is a necessary first step, entailing, for example, the exchange of debt of the companies for equity. However, the more favorable the terms are to the companies, the less favorable they are to the banks, and vice versa. Hence, it usually requires relatively strong oversight on the part of regulators or officials to push both parties to a division of the losses.

Determination of the value of the banks' assets is itself problematic. This is especially so because it is always tempting to assume that debtors will be able to increase their debt servicing once economic activity resumes, although experience suggests that economic activity does not fully resume until financial restructuring is achieved or at least well advanced.

Even when corporates (and the finances of other debtors) are restructured, however, there remains the problem of restoring the banks' balance sheets. This requires valuations of outstanding loans, and appropriate classification as to their risk category. Moreover, once these valuations - which are also contentious - take place, new owners, or at least new capital, must be found for the banks. ${ }^{46}$ If an effort is made to merge weak banks with stronger ones, the terms on which this is done are also problematic.

At the point when these activities are advancing, which necessarily takes time, there is also a question as to how the losses will be financed. Governments can buy the bad paper from the banks' portfolios, but that shifts the burden to the taxpayers. Moreover, if they buy the paper from the banks, the banks have little incentive to collect even what they can from their debtors. Because these are key issues in the recovery of some of the Asian countries, these issues are discussed in more concrete form in section 4.1.4 below.

\section{Interaction of Balance-of-Payments and Financial Crises}

Enough has been said to give an indication of the difficulties entailed when either a balance-of-payments or a financial crisis takes place. Policymakers must take immediate action in circumstances in which the magnitudes of response of the affected parties are unpredictable and expectations are clearly of great importance.

46. In Mexico, it would appear that one of the problems was that new bank owners lent to each other to finance their acquisition of equity interests. This, in turn, meant that the new owners had nothing to lose by undertaking risky loans. 
However, when there is a weak banking system and a balance-ofpayments crisis occurs, the latter can trigger a financial crisis. There are several mechanisms by which this can happen:

1. When banks have been borrowing abroad at a fixed nominal exchange rate to fund their asset base, a devaluation necessarily increases the liability side of their balance sheet and leaves the asset side virtually unaffected. Hence, the banks' balance sheets deteriorate.

2. If borrowers from banks have either borrowed from the domestic banking system but incurred their liabilities in foreign exchange, or themselves borrowed offshore in addition to borrowing from the banks, a devaluation automatically results in a deteriorating of the borrowers' balance sheets. For firms that are engaged in exporting and importing, this effect is likely to be fairly small because export proceeds or domestic currency payments from imports rise pari passu with the devaluation. However, for firms whose costs are determined in the international market but whose receipts are determined in local currency, income and balance sheets are likely to deteriorate. If the banking system was weak prior to the crisis (as was true in most of the Asian crisis countries), the additional hits they take as a result of the devaluation result in further deterioration of their balance sheets.

3 . When the monetary authority responds to a balance-of-payments crisis by tightening money with a consequent increase in interest rates, debtservicing costs to individual borrowers necessarily increase. Again, outstanding loans of marginal borrowers are likely to be tipped into NPL status as interest-carrying costs on their outstanding indebtedness increase.

4. Insofar as fiscal and monetary tightening result in a (necessary) slackening in the pace of economic activity, that too affects borrowers' incomes and cash flows and hence impairs their ability to service their debts.

All of these effects weaken the banking system further. How important each of them is varies from country to country. In Mexico, it is thought that the increase in interest rates was the major factor that added significantly to the 8 percent of bank loans outstanding that were already nonperforming before the crisis. ${ }^{47}$ In Korea, the banks' losses on their holdings of Russian and other securities combined with the inability of domestic firms to service debts to weaken the banking system.

47. See IMF $(1995,62)$. The IMF reports that about 8.5 percent of loans outstanding were past due before the crisis. Foreign currency loans were about one-third of the loans extended by Mexican banks, but many of them were to companies whose income was pesodenominated. As the IMF reports, "The sharp rise in interest rates also affected the peso-loan portfolio. ... When interest rates reached levels as high as 80 percent in the first quarter of 1995 , payments ceased on a large proportion of loans of all types. Banks generally chose to restructure these loans, or simply to suspend interest payments, rather than to be forced to recognize them as high-risk assets and write off a certain amount of their already declining capital by making provisions. Nevertheless, the deterioration in asset quality forced the risk-weighted capital ratios of several Mexican banks below the 8 percent minimum" (62-63). 
The difficulty for policymakers is that when the banking system is very fragile or already in crisis, any actions that are taken to mitigate the balance-of-payments crisis are likely to weaken the banks still further, whereas any measures taken to shore up the domestic banking system (such as the easing of monetary conditions) will make the balance-of-payments crisis worse. Hence, policymakers both in the country and at the IMF are treading a fine line: too much reaction to the balance-of-payments crisis can result in a financial crisis if there is not one already or make it worse if there is one. Conversely, too much attention to the financial situation when the country is already vulnerable to external attack can invite that attack and destabilize the foreign exchange account.

These difficulties are clearly illustrated for the cases of Indonesia and Korea, discussed in the next section. Before that, however, there are two other points. First, countries with a sound banking system, such as Brazil in early 1998, have a much easier time of adjusting and resuming economic growth. In the Brazilian case, there was very little NPL paper in the banking system prior to the devaluation, and Brazilian banks had little or no foreigncurrency debt, whereas their clients' debts were mostly denominated in domestic currency.

Second, and more relevant for understanding the policy response and the IMF packages in the case of the Asian crises, there is clearly a desirable or necessary sequencing for responses to crises. Although it is straightforward (and essential) to allow the exchange rate to depreciate immediately and to tighten money (at least to some extent, depending on the government's balance sheet), there are long time lags involved in financial restructuring. Fortunately, the job does not need to be done perfectly in order for economic activity to reverse its downward course, and there appears to be room for fine-tuning after the initial restructuring. Nonetheless, what does seem evident is that countries do not achieve a rebound and reversal of their difficulties after a twin crisis until such time as they are able to provide sufficient incentives for the banks to resume lending activity. When that does not happen, as for example in Japan in the 1990s, the crisis can transform itself into a long period of sluggish or negligible growth.

\subsubsection{International Monetary Fund Stabilization Programs in Action}

As the above discussion indicates, the number of factors that contribute to the onset of a crisis is large, and each crisis differs in some regards from others. Attempting to evaluate or assess stabilization programs in general is difficult precisely because these differences matter in program design. It is useful, therefore, to provide some case studies of IMF stabilization programs. Each twin crisis of the 1990s has been complex, and books could be and no doubt will be written about each of them. In what follows, emphasis is placed on those factors that seem most important (or that have gen- 
erated most criticism) in evaluating IMF stabilization programs and on linkages between domestic economies and the international financial system. ${ }^{48}$

A first case to be examined is that of Korea, which is perhaps the best example for intensive analysis. Thereafter, features differentiating the financial crisis in Indonesia are discussed.

The Korean Crisis ${ }^{49}$

\section{Background}

As is well known, Korea was one of the poorest countries in the world in the late 1950s and was then widely regarded as a country without serious growth prospects. After economic policy reforms began in the early 1960s, Korea began growing at sustained rates previously unheard of in world history. ${ }^{50}$ Real GDP grew an average 13 percent per annum in the decade starting 1963. High growth rates continued into the 1990s, and Korea's real per capita income in the mid-1990s was more than eight times what it had been in the early 1960 s.

In general, economic liberalization proceeded throughout the first thirtyfive years of Korea's rapid growth. In 1960, the country had had the usual developing-country mix of an overvalued exchange rate supported by quantitative restrictions on imports (and a black market in foreign exchange), consequent high walls of protection for domestic manufacturers, price controls on many key commodities, credit rationing, a large fiscal deficit, one of the highest rates of inflation in the world, and a huge (averaging around 10 percent of GDP over the period 1953-58) current account deficit financed largely by foreign aid inflows. ${ }^{51}$ Indeed, when the government of

48. It should be recalled that focus here is on the extent to which stabilization programs enabled a cessation of capital flight and provided a basis for restoration of growth. One criticism of IMF programs have been that there were too many conditions attached which, while perhaps desirable in themselves or in the long run, were not essential to the stabilization effort. That concern is assessed in the paper by Goldstein (chap. 5 in this volume).

49. The IMF documents cited in this section may be found at [http://www.imf.org/external/country/KOR/index.htm].

50. Taiwan's rate of economic growth was equally rapid. There is truth to the frequently made assertion that policymakers in each country watched the evolution of the other's economy and policies, and that competition spurred each on. Prior to the crisis in the late 1990s, most observers would have claimed that the major difference between the Taiwanese and Korean economies was the relatively small scale of Taiwanese enterprises contrasted with the large share of the Korean chaebol in the Korean economy. There were other differences, however: perhaps because of greater strategic insecurity, the Taiwanese held very large foreign exchange reserves in relation to the size of their trade or their economy; the Taiwanese dollar showed no tendency for real appreciation; and Taiwan's current account had been consistently in surplus. The Taiwanese financial system also appears to have been considerably sounder than that of Korea, and the rate of expansion of domestic credit in the mid-1990s was much lower than that in Korea.

51. See Krueger (1979) and Frank, Kim, and Westphal (1975) for an account of the early period of Korea's rapid development. 
Syngman Rhee was overthrown in 1960, one of the main sources of dissatisfaction was reported to be corruption.

First steps included moving to a more realistic (and constant real) exchange rate for exports, and the relaxation of restrictions on importing for exporters. Thereafter, imports were gradually liberalized and the exchange rate regime unified by the early 1970s. In 1964, a major fiscal and tax reform brought the government finances into a much-improved balance, and the rate of inflation fell. ${ }^{52}$ Price controls were gradually removed, discrimination and price controls on key agricultural commodities were replaced with a protective regime for agriculture, and nominal interest rates were permitted to move to levels that at least made the real interest rate positive. However, credit rationing continued because it was below a market-clearing rate (see Hong 1981). Only in the late 1980s were interest rates freed.

When economic policy reform began, Korea's exports were only about 3 percent of GDP, whereas imports were about 13 percent. Policymakers therefore began focusing on measures to increase exports. They did so by encouraging all exports uniformly, but nonetheless they had something that might be regarded as being close to an "export theory of value." Any firm that could export was rewarded in proportion to the foreign exchange receipts from exporting. Many of the firms that were initially successful were chaebol (although they were very small at the time, and some Korean analysts today do not regard the Hyundais, Samsungs, and the like of the 1960s as chaebol at all). Because they were successful, they grew rapidly. They received new loans as their exports grew and as they expanded into new exporting activities. ${ }^{53}$

The chaebol were successful exporters and, for the first decade or more of Korean growth, were regarded almost as the heroes of Korean development. They were rewarded for export performance. In addition, when the authorities wanted a venture undertaken, they did so with the implicit guarantee of the government that credit, tax exemptions, and other support would be available to make the venture profitable. ${ }^{54}$ However, the chaebol

52. The oil price increase of 1973 triggered a large increase in the rate of inflation, but the country rapidly returned to single-digit inflation. By the mid-1980s, there were even occasions when the domestic price level was falling.

53. Some of these activities were chosen by the chaebol. On occasion, however, the authorities suggested to chaebol owners that they should move into certain lines of production. This attempt to "pick winners" was not always successful; when it reached its height in the heavy and chemical industry (HCI) drive of the mid-1970s, the rate of economic growth and of export expansion slowed substantially, and policies were reversed by the late 1970s. When chaebol incurred losses while undertaking these mandated activities, the banks were directed to extend additional credit to the chaebol, thus setting a precedent for later difficulties.

54. It is important to underscore that these government "rewards" were there in the context of the export drive. When chaebol could not produce competitive exports, there was little support. Even in the HCI drive- the most industry-specific interventionist phase of Korean policy - the output from HCI industries was to be exported within a specified period. When it became clear that that performance test was not being passed, the entire thrust of the policy was reevaluated. 
were on the whole remarkably profitable and had little difficulty in servicing their (subsidized) debt.

The extent to which the Korean economy changed structure is remarkable. Exports and export earnings (the dollar price index of traded goods being stable in the 1960s) grew at over 45 percent annually. Exports as a percentage of GDP rose from 3 percent in 1960 to 8.5 percent in 1970 to 35.2 percent in 1980; imports also rose, from their 10 percent level in 1960 to 43 percent of GDP in 1980. Hence, the Korean economy was much more open as growth progressed..$^{55}$

In the early years, rationed credit financed a large fraction of new investment, especially in the manufacturing sector. The subsidies implicit in this credit served as a stimulus to industry and permitted much more rapid expansion than would have been possible had companies had to rely on reinvesting their own profits. ${ }^{56}$ The real rate of return was so high that all the chaebol would happily have borrowed more had they been able to; most of them, as reported by Hong (1981), borrowed additional funds at the much higher curb market rates. That would imply that the lending at controlled interest rates was, at least in the early years, equivalent to an intramarginal subsidy to the chaebol. Estimates of their rates of return suggest that the chaebol were highly profitable at that time even without subsidies. Indeed, given the huge distortions in the economy that prevailed in the late 1950s, it is likely that in the 1960s, at least, almost any reasonably sensible venture into unskilled labor intensive exportable production had a high real rate of return.

As already mentioned, by 1964, the borrowing rate from the banks was positive in real terms. Over the following three decades, there were further liberalizations of the financial system as the real interest rate charged for loans rose, although credit was still rationed. At the same time, the real rate of return on investments naturally fell as the very high initial returns obviously could not be sustained. Hence, the implicit subsidy to the borrowers who received credit diminished sharply. When, in 1996 and 1997, gross profits of some of the large enterprises fell sharply, their ability to service their debt was impaired. However, in keeping with tradition, banks began "ever-

55. Some of the increase in imports was of course intermediate goods used in the production of exportables. However, the percentage import content of exports remained fairly stable at around 35 percent of the value of exports over the period of rapid growth. From 1960 onward, exporters were entitled to import virtually anything that they might use in producing exportables with little paperwork; in addition, they were permitted to import a "wastage" allowance, which they were free to sell on the domestic market. Thus, the de facto liberalization exceeded that which took place because of removal of quantitative restrictions and lowering of tariffs. With an average tariff rate in the tariff schedule of around 15 percent in 1970, average tariff collections as a percent of imports were about 6 percent.

56. In much of the public discussion of the reliance of firms in crisis countries on borrowing, what seems to be forgotten is that, starting from very low levels of income and development, there is very little equity, and a large fraction of investment must therefore be financed through other channels. 
greening" the loans, lending additional funds to the borrowers to enable them to make interest payments. Hence, actual NPLs were building up in the banking system, although it is probable that it was thought that the decline in profits was temporary.

There is another aspect of Korean growth that is important in understanding the background to the crisis. That is, when rapid growth started in the early 1960s, the Korean saving rate was very low, and even negative by some estimates. With more rapid growth, domestic saving began growing rapidly, rising from around zero percent of $\mathrm{GDP}^{57}$ in 1960 to 15 percent of GDP by 1970 and 25 percent of GDP by 1980 . However, in the early years and until the late 1970s, profitable investment opportunities greatly exceeded domestic savings. As a result, domestic savings were supplemented by borrowing from abroad, equaling as much as 10 percent of GDP in years during the 1960s. ${ }^{58}$

The Korean government guaranteed loans and determined the maximum that could be borrowed, allocating borrowing rights among exporting firms. Because the foreign interest rate was well below the domestic interest rate (especially in the curb market) and the real exchange rate fairly stable for exporters, there was intense competition for foreign loans.

As domestic saving rose, the proportionate reliance on foreign resources for supplementing domestic saving to finance investment fell. By the 1980s, the domestic saving rate was in excess of 30 percent, and the current account went into surplus for several years in the mid-1980s. ${ }^{59}$ Beginning at this time, the American government in bilateral trade negotiations began to pressure the Koreans to let the won appreciate in order to reduce the bilateral trade deficit with the United States. ${ }^{60}$ Most Korean economists believed by the mid-1990s that it would be in Korea's best interests to have some real depreciation of the won, but the pressures not to do so prevented it. The

57. In 1960, it is estimated that private saving was a positive 3.2 percent of GDP, whereas government saving was a negative 2 percent of GDP. Foreign sources financed 78 percent of investment, which was 10 percent of GDP. See Krueger (1979, 206-07). In 1960, most foreign resources were foreign aid.

58 . Most of the capital inflow was from the private sector-largely commercial bank lending - by the late 1960s. Foreign aid had peaked in 1958 and was less than 2 percent of GDP by the mid-1960s. The current account deficit was sustainable because of the profitability of investment and the declining debt-service ratio that resulted from such rapid growth of exports and of real GDP.

59. Korean policymakers viewed the emergence of the current account surplus as a transitory phenomenon explicable by "three blessings": the fall in oil prices in the mid-1980s, the drop in world interest rates (so that debt-servicing costs declined), and the boom in Korea's trading partners, especially Japan. The current account turned positive in 1986, rose to a peak of 8.0 percent of GDP in 1988, fell to 2.4 percent of GDP in 1989, turned negative ( -0.8 percent) in 1990, and remained negative in the 1-2 percent range until 1997, when the deficit increased to 4.7 percent of GDP.

60. Korea was running a bilateral surplus with the United States and a bilateral deficit with Japan, and policymakers resisted as far as they could these pressures. One response was to ask the American authorities whether they should devalue with respect to the yen while they appreciated with respect to the U.S. dollar! 
won exchange rate was not fixed, the range within which it fluctuated was relatively narrow: it appreciated from 890 won per dollar at the end of 1985 to 679 won per dollar in 1989 , and thereafter it gradually depreciated to 808 won per dollar in 1993, appreciating again to 788 won per dollar in 1995. At the end of 1996 it stood at 844 won per dollar, and of course it depreciated almost 50 percent in $1997 .{ }^{61}$ Thus, for the decade prior to the 1997 crisis, there had been little change in the real exchange rate. ${ }^{62}$

\section{Events Prior to the Crisis}

Thus, by the mid-1990s, Korea had sustained thirty-five years of rapid growth. Although there had been periods of difficulty—both slowdowns and overheating-Korean policymakers had met their challenges successfully. As noted by the Organization for Economic Cooperation and Development (OECD), the country had come from being one of the poorest developing countries in 1960 to having a per capita income equal to that of some OECD countries, with a higher rate of economic growth. ${ }^{63}$

The late 1980s had witnessed the introduction of a democratic process into Korea. The elected governments chose to liberalize further, including especially the financial sector and international capital flows. ${ }^{64}$ In 1992-93 there was a "growth recession," as the growth rate slowed to just over 5 percent (contrasted with rates of over 9 percent in the preceding two years and an average rate above 8 percent in the preceding decade). One response was to ease monetary policy: domestic credit expanded by over 18 percent in 1994, 14 percent in 1995, and 21 percent in $1996 .{ }^{65}$ Real GDP growth responded, exceeding 8 percent in 1994 and 1995.

However, there is ample evidence that, despite this cyclical recovery, the profitability of the chaebol was declining and the condition of the banks was deteriorating. Turning first to the chaebol, data for the thirty largest ones indicate that the return on assets, which stood at only 2.0 percent in 1994 and 2.5 percent in 1995, fell further to 0.8 percent in 1996 and was a negative 0.7 percent in 1997. Return on equity fell from 6.9 and 8.7 percent to 2.7 and minus 2.9 percent over the same years, while the rate of growth of operating income was minus 14.4 percent in 1996 (Hahm and Mishkin 1999, 60).

Even during the cyclical boom years of 1994 and 1995, the financial in-

61. Exchange rates, saving rates, and current account deficit data are all taken from various issues of the IMF's International Financial Statistics unless otherwise noted.

62. This may be somewhat misleading. The late 1980s was a time of the "three blessings" (low international interest rates, low oil prices, and a favorable international economy, especially Japan) for Korea.

63. For an account of the Korean economy in the mid-1990s reflecting this consensus view, see OECD (1994).

64. See the OECD (1994) description of the five-year financial liberalization plan.

65. This rate was not markedly faster, however, than it had been over the entire preceding decade. Hahm and Mishkin $(1999,21)$ reject the notion that liberalization of the capital account was responsible for the increase in domestic credit, but they note that it did play a role in permitting the banks to take on greater exposures to foreign exchange risk. 
stitutions were borrowing abroad to finance their lending to the corporate sector (especially the chaebol). As a consequence of financial liberalization, twenty-four finance companies were transformed into merchant banks, which enabled them to enter into foreign exchange transactions. Thus, both the banks and the nonbank financial institutions increased their exposure heavily, and much of the onlending consisted of dollar-denominated obligations. According to Bank of Korea data reported in Hahm and Mishkin (62), foreign currency debt constituted 9.8 percent of total corporate debt in 1992, rising to 11.5 percent in 1996 and 16.4 percent in 1997. However, corporate debt itself rose from about 130 percent of GDP in 1991 to 150 percent in 1996 and 175 percent in 1997.

There were other signs that growth was not as solidly based as it had been. The incremental capital-output ratio, which had stayed around 4 for many years, had risen to 5 (often deemed to be the highest sound number) in 1991 and then rose to 6 and stayed fairly steady at that level until the crisis.

In 1996, the dollar value of exports of goods rose only 4 percent, contrasted with increases of 15 and 32 percent in the preceding two years. This very low rate reflected largely the faltering sales of semiconductors and the turnaround in the fortunes of Samsung: the terms of trade turned sharply against it, as the unit price of semiconductor chips fell by 70 percent, leading to a marked deterioration in Korea's terms of trade - about 13 percent based on unit value statistics.

External liabilities in foreign currency rose by 32 percent in 1994, 35 percent in 1995, and 37 percent in 1996. Of that total, short-term liabilities were 56 percent; these short-term liabilities were 2.79 times foreign exchange reserves at the end of 1996. The ratio of gross external liabilities to GDP (including the offshore borrowings of Korean banks and the overseas borrowings of their overseas branches) had risen from 0.20 in 1992 to 0.31 by the end of $1996 .{ }^{66}$

Hence, a close examination of the data on the Korean economy would have revealed that the economy's financial fundamentals had deteriorated quite substantially during the 1990s, especially if the short-term impact of the 1994-95 cyclical recovery was discounted. The macroeconomic aggregates, however, appeared fairly sound. The fiscal accounts were in balance, and, indeed, there had been fiscal surpluses equivalent to one-half of one percent of GDP or less in each year from 1993 through 1996. The current account deficit had, of course, increased sharply, as already noted, from 1.74 percent of GDP in 1995 to 4.42 percent of GDP in 1996. However, if the real exchange rate was examined only in the 1990s, it appeared to have remained fairly stable; the inflation rate was less than 5 percent per annum, and the saving rate was well over 30 percent. Moreover, as will be explored 
in more detail below, the condition of the banks was probably considerably weaker than the official numbers indicated.

\section{The Crisis}

A number of events took place early in 1997 that surely eroded confidence. One of the large chaebol, Hanbo, went bankrupt early in the year. Given that it had been widely believed that the large chaebol were "too big to fail," this in and of itself must have resulted in some loss of confidence and a reexamination of Korea's creditworthiness. Moreover, 1997 was an election year, with the presidential elections set to be held early in December. That the market anticipated difficulties is reflected in the fact that the Korean stock exchange index fell from 981 in April 1996 to 677 by the end of March 1997 and to 471 at the end of October, even before the outbreak of the currency crisis.

However, although the net and gross foreign (and especially short-term) liabilities of the banking and financial systems were continuing to increase, there was no visible evidence of crisis until the final quarter of the year. The Thai crisis had exploded in June, and the Indonesian crisis had begun during the summer of 1997, but most observers were confident, given Korea's past history, that Korea would not be affected. ${ }^{67}$ Korea's offshore banks were holding paper from Indonesia, Russia, and other countries with dollar liabilities, which would further deteriorate the net foreign asset position, but that was not widely known at the time.

However, capital flight began early in the fourth quarter of the year. In many instances, it was simply a refusal to roll over short-term debt. However, other factors contributed: Korea's sovereign risk status was downgraded by Standard \& Poor's in October; NPLs in the banking system doubled from the end of 1996 to fourth quarter 1997, reaching 7.5 percent of GDP by that time, owing largely to the bankruptcy of six chaebol and the sharp drop in the Korean stock exchange. However, once it became known that reserves were decreasing, others sought to get out of won, and the capital outflow intensified rapidly. ${ }^{68}$ Total reserves less overseas branch deposits and other unusable foreign exchange were $\$ 22.3$ billion at the end of October and had fallen to $\$ 7.3$ billion by the end of November. ${ }^{69}$ It is reported that, by the time the IMF was approached, gross reserves were being depleted at a rate so rapid that they would have approached zero within forty-eight hours. In the program presented to the IMF board, it was re-

67. The author was at a conference of Korean economic policymakers in August 1997 and the mood was one of deep gloom. Many of the participants were extremely pessimistic about the chaebol, the state of the financial system, and the potential for reforms of economic policy.

68 . However, even in November, the finance ministry was issuing reassuring statements, and private forecasters were minimizing the likelihood that Korea would approach the IMF. For a representative account, see John Burton's "Korean Currency Slide Shakes Economy," in the Financial Times, 12 November 1997, 5.

69. Data are from Hahm and Mishkin (1999), table 11. 
ported that usable reserves had dropped from $\$ 22.5$ billion on October 31 to $\$ 13$ billion on November 21 and $\$ 6$ billion on December 2. ${ }^{70}$

\section{The IMF Program}

All three presidential candidates had declared repeatedly that under no circumstances would they approach the IMF. When the government did approach the IMF, the IMF's problem was complicated by several things: (a) it was not known who the new president would be and hence with whom the IMF would have to deal on the economics team; (b) there was very little time to put together a program, and, both because Korea had been viewed as sound until recently and because the candidates had all said they would not approach the Fund, there had been less preliminary work done than was usually the case, ${ }^{71}$ (c) the exchange rate was depreciating sharply after the end of October, and when the band was widened to 10 percent on November 19, the rate of depreciation began accelerating rapidly; and (d) as already mentioned, the government was rapidly running out of foreign exchange reserves and would soon be forced to default on its obligations (see Boughton 1999). The high short-term indebtedness meant that foreigners could get out of won simply by refusing to roll over outstanding debt. ${ }^{72}$

The initial program was negotiated over the period November 26 to December 3. As stated in the memorandum to the executive directors as the staff sought approval of the program, "Owing to the critical situation in Korea, and the very short period in which program negotiations had to be completed, it was not possible to fully specify the program. Therefore, emphasis was placed on strong prior actions to demonstrate the government's seriousness to strictly implement its policy commitments." Even as the program was approved in December, the board was told that it would be reviewed in January 1998 (when, among other things, the new president and economics team would be known).

The initial program set forth as its objectives "building the conditions for an early return of confidence so as to limit the deceleration of real GDP

70. Other factors also contributed. A financial reform bill, proposed by a blue ribbon committee, had been turned down by parliament, and it was not clear whether the government had legally guaranteed the foreign exchange liabilities of the financial institutions. Although interest rates had risen by about 200 basis points, the Bank of Korea was nonetheless injecting liquidity into the system, which reversed the increase.

71. The fact that the Thai and Indonesian crises had already occurred no doubt diverted some of the attention that Korea otherwise might have received. At that time, too, it must have been anticipated that there would be Malaysian and Philippine programs.

72. Hahm and Mishkin (1999) point out that "the speculative attack was not in the usual form of direct currency attack to exploit expected depreciation. Due to the tight regulation on currency forwards which should be backed by corresponding current account transactions and the absence of currency futures markets inside Korea at the time, opportunities for direct speculative attack had been much limited. Rather, the drastic depreciation of Korean won was driven by foreign creditors' run on Korean financial institutions and chaebols to collect their loans, and by foreign investors to exit from the Korean stock market" (25). 
growth to about 3 percent of GDP in 1998, followed by a recovery towards potential in 1999; containing inflation at or below 5 percent; and building international reserves to more than two months of imports by end-1998" (IMF 1997). The staff memorandum stated that there were three pillars to the government's program: the macroeconomic framework; ${ }^{73}$ restructuring and recapitalizing the financial sector, and reducing the reliance of corporations and financial institutions on short-term debt.

The 5 percent inflation target looked ambitious in light of the large depreciation of the won (from the mid-800s per dollar to almost 1,800 per U.S. dollar at its peak) and the share of traded goods in GDP. ${ }^{74}$ To achieve that objective, the liquidity that had been introduced into the system in prior weeks (in an effort to support the chaebol) was removed, and money market rates were raised sharply. In the words of the staff, these rates would "be maintained at as high a level as needed to stabilize markets" (5). Day-to-day monetary policy was to be geared to exchange rate and short-term interest rate movements, and exchange rate policy was to be flexible with intervention "limited to smoothing operations."

The 1998 budget as passed by the government had projected a surplus of about 0.25 percent of GDP. However, Fund staff estimated that lower growth and the altered exchange rate would reduce the balance by 0.8 percent of GDP and that it would require 5.5 percent of GDP to recapitalize the banks to meet the Basel minimum capital standards. It was assumed that these funds would have to be borrowed, and interest costs $(0.8$ percent of GDP) were therefore also included in the altered budget estimates. These factors would, on IMF estimates, have shifted the fiscal account into deficit to about 1.5 percent of GDP in 1998. As stated by staff, "In order to prevent such a deficit and alleviate the burden on monetary policy in the overall macroeconomic adjustment, fiscal policy will be tightened to achieve at least balance and, preferably, a small surplus." The program therefore called for fiscal changes approximately offsetting the negative anticipated changes and thus for maintenance of the fiscal stance as anticipated prior to the crisis, with the 1.5 percent of GDP cuts equally distributed between government expenditures and revenues. The government initially raised some taxes to yield about 0.5 percent of GDP.

The second leg of the program was financial restructuring. As already indicated, NPLs were large and increasing prior to the crisis. The deprecia-

73. Much of the controversy surrounding the Korean program centers on whether the program tightened fiscal policy too much. This is discussed below. It should be noted that the IMF staff's introduction of the macroeconomic program indicated that the program would involve "a tighter monetary stance and significant fiscal adjustment" (5).

74. As stated in the Request for Standby, "The inflation target reflects a very limited passthrough of the recent depreciation of the won to the aggregate price level. ... In order to achieve the inflation objective, the government will aim to reduce broad money growth (M3) from an estimated 16.4 percent at end-September to 15.4 percent at end-December 1997, and to a rate consistent with the inflation objective in 1998 " (5-6). 
tion of the exchange rate increased debt-servicing obligations for chaebol and financial institutions, as did the increase in interest rates that came about with monetary tightening. The details of financial restructuring are intricate enough that they cannot be delved into here in any detail. Suffice it to say that an exit policy was to be adopted to close down weak financial institutions, recapitalizing the remaining banks (through mergers or other means). A deposit guarantee was to be phased out at the end of December 2000 and replaced with deposit insurance for small depositors only. Transparency was to be increased in a variety of ways. Large firms were to be audited by international accounting houses. Supervisory functions were to be reorganized, the Bank of Korea given much greater independence, and so on. Finally, the government undertook to withdraw from any influence over lending decisions, leaving those to the financial institutions.

One important point to note in terms of bank restructuring is that it required a prior, or at least concurrent, restructuring of the chaebol finances. Given their very high debt-equity ratios $^{75}$ (for one chaebol at the height of the crisis, the debt-equity ratio reached 12:1), financial viability, where feasible at all, would surely require swaps of debt by the chaebol to the banks, giving the banks equity in return.

The IMF standby also called for the Korean government to set a timetable to meet its World Trade Organization (WTO) trade-related commitments to remove restrictive import licensing and "diversification program" (which discriminated against Japanese imports). Equally, the program stipulated further capital account liberalization including, importantly, increasing the ceiling on aggregate foreign ownership of Korean shares from 26 to 50 percent by the end of 1997 and then to 55 percent by the end of $1998 .{ }^{76}$ Remaining elements of capital account liberalization, which had already been agreed to with the OECD, were to be accelerated with the new program announced by the end of February 1998. In addition, restrictions on direct foreign borrowing by chaebol were to be eliminated. The first of these measures-permitting increased foreign ownership-encouraged foreign investment and enabled the possibility of foreign control of financial institutions, among other things.

The standby then addressed corporate governance and corporate financial structure issues, noting that the only scrutiny over chaebol investments, even of large scale, had been by bank managers "whose appointment has

75. These high debt-equity ratios were public knowledge. The Financial Times published data on debt-equity ratios for twenty chaebol on 8 August 1997. The highest was Sammi, with 33.3 times as much debt as equity; Jinro had 85 times as much debt as equity and Halla 20 times; Hyundai's debt was 4.4 times its equity, and so on. Profits were relatively small as a percentage of assets or sales. In Samsung's case, for example, net profits were 179.5 billion won on sales of 60 trillion won and total assets of 51 trillion won. Nine of the twenty chaebol listed in the Financial Times on that day had taken losses.

76. This measure - which some have criticized as being beyond the Fund's mandate-enabled a more rapid recapitalization of the banks than would otherwise have been possible. 
traditionally been influenced by the government." It then anticipated that shareholders' and directors' oversight should improve, especially in conjunction with increased opportunity for foreign purchases of shares. One important element of these changes was to be the reform of bankruptcy laws, with governmental agreement that there would in future be no financial support, forced mergers, or tax privileges for individual firms.

The final components of the standby were those related to data provision and monitoring, which need not be of concern here. The staff then addressed the issue of the reasons for external support. It first noted that the current account deficit was expected to decline markedly in 1997 to about 3 percent of GDP, and then - with export growth and won depreciation - to about 0.5 percent of GDP in 1998. However, the very high level of shortterm debt was seen to be worrisome. As stated in the standby, "It is difficult to estimate with any certainty the likely developments in capital flows ...., given the uncertainty surrounding the rolling over of private sector shortterm debt and the recent collapse in market confidence. . . . The working assumption is that, on the basis of the beneficial effects on market confidence. ... The working assumption is that, on the basis of the beneficial effects on market confidence of the announced program and the large financing package, the bulk of the short-term debt will be rolled over. Under this scenario, the purpose of the exceptional financing would be largely to reconstitute reserves. For this outcome to materialize, it is critical that the financing package provided is adequately large and the program is perceived to be strong. ... It is anticipated that a comprehensive financing package of about $\$ 55$ billion will be provided on a multilateral and bilateral basis ..."(12).

\section{Aftermath of the Crisis}

For at least two weeks after the announcement of the IMF program, questions remained as to whether the downward slide had been halted. ${ }^{77} \mathrm{By}$ late December, however, the exchange rate had stabilized, and by midJanuary, foreign banks announced a $\$ 24$ billion package of rollovers and new money (Financial Times, 30 January 1998, 11).

Domestic economic activity slowed markedly in 1998. For the year as a whole, real GDP fell by 5.8 percent, contrasted with the Fund's projected 3 percent. The unemployment rate, which had been 2.2 percent at the end of the third quarter of 1997, rose throughout 1998 and peaked in the first quarter of 1999 at 8.4 percent. The seasonally adjusted industrial production index fell by 15 percent from the end of 1997 to the second quarter of 1998 .

77. Because of this, it is very difficult to accept the argument that the Fund program was "too stringent." Indeed, given those uncertainties, it is more plausible to argue that the program might have been even more restrictive initially. 
Thereafter, it rose, reaching its precrisis level by the end of 1998 and 144.9 at the end of 1999.

The external accounts improved markedly. There was a sharp drop in imports in immediate response to the crisis, and a much-increased current account balance: whereas exports were slightly lower in dollar terms in 1998 than in 1997, imports fell 22.4 percent and the current account balance was equal to an astonishing 12.5 percent of GDP for the year. Foreign exchange reserves rose in response, reaching $\$ 74$ billion by the end of 1999 and $\$ 83.5$ billion by the end of the first quarter of 2000. The decline in real GDP ended in mid-1998, and by the end of the year, real GDP had exceeded its precrisis level. For 1999, real GDP growth exceeded 9 percent, and it was projected to attain that same rate for 2000 .

After early 1998, the nominal exchange rate appreciated in dollar terms, entering the year 2000 at around 1,100 to the dollar, as contrasted with 1,800 to the dollar at the peak of the crisis. Moreover, prices at the end of 1998 were about 7 percent higher than at the end of 1997; in 1999 the rate of inflation was just 0.8 percent, as measured by the consumer price index.

Progress in restructuring the financial sector was necessarily considerably slower. Although interest rates had fallen below their precrisis levels by the end of 1999, restructuring of chaebol and financial institutions met considerable resistance. ${ }^{78}$ Government policy pronouncements and actions have continued to push reforms, but the pace of reform has been much slower than with regard to the balance of payments and external finances.

By early 2000, it was certainly the case that the Korean recovery had been more rapid and more pronounced than had been anticipated by any. Although there was an underlying question as to whether the financial reforms had been effected in ways that would enable further financial development on a sound basis, there was no doubt that recovery had come, and come dramatically. Korea was regarded as the most successful country in pulling out of the crisis.

After the initial program of 3 December 1997, there were LOIs dated 24 December 1997, 7 February 1998, 2 May 1998, 24 July 1998, 9 December 1998, 10 March 1999, 2 November 1999, and 12 July $2000 .{ }^{79}$ In each, targets were revised and the program was amended as judged appropriate. In general, the fiscal deficits achieved - especially in 1998 - were smaller in magnitude than target, whereas foreign exchange reserves exceeded target. By 1999, fiscal objectives were once again to reduce the budget deficit as the recovery accelerated more rapidly than had been anticipated. The 12 July

78. See, for example, "Boxed into a Corner," by John Burton (Financial Times, 23 November 1998, 17), whose header read "South Korea's chaebol are fighting a stiff rearguard action against government reforms but the conglomerates are being forced to change their ways."

79. These are all available on the IMF's website: [http://www.imf.org/external/np]. 
2000 LOI was the final review under the standby, which was set to expire 3 December 2000.

\section{How Good Was the Fund's Program?}

There are three key issues on which the Fund has been criticized with respect to the Korean program after the East Asian financial crisis. The first pertains to the degree of monetary and fiscal tightening that accompanied the onset of the program, and the second is the extent to which issues such as corporate governance needed to be a part of the program. ${ }^{80}$ The third is the size of the loan package, although on that issue there are criticisms both that it was too small and that it was too large.

Turning to the degree of monetary and fiscal tightening that took place, Stiglitz has been perhaps the foremost spokesman for the view that tightening interest rates may in fact have been counterproductive during the crisis phase. As was seen in section 4.1.3, there is a trade-off between tightening the money supply and letting the exchange rate depreciate more, and both of these measures have their dangers. ${ }^{81}$ Given the rate at which reserves were dwindling and the exchange rate depreciating in November and early December 1997, it seems absolutely clear that monetary tightening had to take place. Its extent had to be such that a strong signal was provided (especially in light of the elections and the new government) that the government was serious about addressing the situation. Indeed, judging by the continued slide of the won in the first two weeks after announcement of the IMF program, a case could even be made that perhaps monetary policy should have been even tighter! $!^{82}$ Certainly, with respect to monetary policy, it seems evident that it was at the very beginning none too tight. One might question the rate at which it eased in 1998 once the exchange market had stabilized and the severity of the downturn in domestic economic activity

80. For criticisms of the Fund with respect to the monetary and fiscal tightening, see Jeffrey Sachs, "The Wrong Medicine for Asia," (New York Times, 3 November 1997) and Furman and Stiglitz (1998); for criticisms of the Fund with respect to the breadth of coverage of the program, see Feldstein (1998).

81. Stiglitz has argued that interest rate increases may have increased the degree of exchange rate depreciation and financial instability because only riskier investments would be undertaken at higher interest rates or borrowers had more difficulty servicing their debts. Tests of this hypothesis provide strong evidence that this was not the case in Korea. Cho and West (1999) tested the relationship between interest rates and exchange rates in Korea over the period December 1997 to mid-1999 and found that "the high interest rate policy after the crisis contributed to stabilizing the exchange rate in the short run." However, they found the recovery of the foreign currency liquidity position the longer-run determinant of the exchange rate. However, recovery in reserves came about because of the turnaround in the current account balance, itself a function both of the IMF loan and of the exchange rate.

82. See Financial Times, 12 December 1997, 17. John Burton, in "This is an Unusual Situation," wrote that "In the week since it signed up . . ., South Korea has seen its currency drop by nearly 30 percent against the dollar. Corporate bond yields are up nearly 5 percentage points to 23 percent, and the country's banks and companies seem as much in danger as ever of defaulting. . . . As the won dropped another 10 percent within four minutes of opening yesterday, some people began to fear that there might be a meltdown in financial markets." 
became evident, but the criticism of the initial part of the program in that regard seems inappropriate.

Fiscal policy can, however, be questioned. As seen above, the first program took into account the impact on government expenditures of the stabilization program; although expenditures were to be reduced and taxes raised, these were intended to offset other increases in expenditure (e.g., larger interest payments at higher interest rates) and lower revenues (because of anticipated recession). There is no doubt that the first LOI did underestimate the extent of the downturn, anticipating 3 percent in contrast with the actual reduction of more than 5 percent of GDP. However, adjustments were made in subsequent reviews and LOIs. For example, the September 1998 original target was for a central government fiscal deficit of 7 trillion won; the revised target was 10 trillion won; the actual deficit for that period was 5.7 trillion won. Even for the March 1999 quarter, the target deficit was 23.5 trillion won and that achieved was 19.7 trillion won. Hence, although there can be questions about whether the original fiscal targets were too tight, subsequent IMF missions certainly assented to easier targets, and the actuals were smaller than the target deficits for most of the recession and recovery period. ${ }^{83}$

The second criticism - that the programs interfered more in internal economic policies than was necessary - is more difficult to evaluate. On one hand, financial restructuring was absolutely essential, first as a very credible intent, or capital outflows would have continued, and second as a prerequisite for economic recovery. Moreover, because the devaluation and higher interest rates would both weaken the financial sector in the short run (and this would be understood by the markets), failure to address the issue would clearly have increased the severity of the recession and delayed, if not aborted, the recovery. And financial restructuring could not be satisfactorily undertaken without addressing the very high debt-equity ratios of the chaebol, which immediately led into issues of corporate governance, supervision, and the like.

There is no doubt that financial restructuring is inherently domestic and politically difficult because it entails sorting out property rights among claimants and, perhaps even more important, allocating the losses among various groups - at least between shareholders, borrowers, and taxpayers. Were there an international institution or organization (such as the Bank for International Settlements [BIS]) that supported financial restructuring efforts, there would of necessity have to be close coordination between that agency and the IMF when twin crises arose. In the absence of such an agency, however, it would appear that the IMF cannot credibly support a

83. I have not been able to ascertain the extent to which this shortfall from deficit targets was the result of more rapid expansion of GDP than anticipated and the extent to which there were other factors. 
stabilization program without being assured that appropriate financial restructuring will take place.

These issues would be much less pressing if countries' governments, financial institutions, and corporations did not take uncovered debtor positions in foreign exchange. However, as long as these positions are taken ${ }^{84}$ and financial institutions are already weak at the outset of a crisis because of NPLs, financial restructuring will often be an essential part of stabilization programs. ${ }^{85}$ Although improved incentives for financial institutions to manage risk appropriately and appropriate strengthening of prudential supervision would significantly reduce the incidence of twin crises, addressing these issues when they do arise is unavoidable.

There are also questions as to whether financial restructuring has gone far enough. As already mentioned, the Korean government has encountered major political resistance to efforts to restructure the finances of the chaebol and to attain arms'-length transactions between the chaebol and the financial institutions. The question, however, would be whether the international community should be more insistent upon rapid restructuring than it was; to the extent one can criticize the evolution of economic policy in Korea since the crisis, that criticism would be with respect to the slowness with which financial restructuring has occurred. ${ }^{86}$

The third issue (for all the Asian programs) was whether forthcoming support from the IMF and the other bilateral and multilateral institutions was of the appropriate size. Some argue that the financing should have been larger, at least enough to cover outstanding short-term indebtedness, and should have been available without conditions. To this proposal there are several responses. First, if a country does not adjust its policies, it is likely that capital outflows will continue, and capital flows are not limited to short-term debt. A larger size of program would then only result in larger capital outflows. A larger volume of foreign financial resources coupled with a smaller adjustment package would likely result in a greater capital outflow, and hence be self-defeating.

The other criticism-that the financial support should have been smaller - is based both on the outcome (not all resources were used) and on the proposition that there is moral hazard involved in IMF lending. Although there is no doubt moral hazard, those top policymakers who were

84. Hahm and Mishkin (1999) estimate that more than 60 percent of the foreign currency obligations were uncovered at the time of the crisis.

85. This is vividly illustrated by the contrast between Brazil's crisis in the early months of 1998 and the Asian crises. In Brazil, the financial system had few NPLs when the real was allowed to depreciate, and there appear to have been few foreign currency-denominated liabilities. The Brazilian recession was both short and shallow, and recovery was remarkably rapid, surprising most observers.

86. A great deal of the focus in the 12 July 2000 LOI, which is the last one, is on issues pertaining to further financial restructuring, including the need for reform of investment trusts and the corporate sector. 
in office in the run-up to the crisis in Korea (as well as in Thailand, Mexico, Brazil, and Indonesia) lost their jobs very quickly in any event. Certainly, the risk to top economics officials must serve as at least a partial offset to moral hazard that would otherwise be entailed in their willingness to borrow and risk crises. Moreover, as noted, given conditions at the time of the IMF loan, it seems evident that the financial package should have been more than a "minimum" in order to reduce or eliminate expectations of a further free-fall of the exchange rate or of a financial crisis.

On most criteria, therefore, one can evaluate the IMF programs in Korea as having been successful: hindsight enables a clearer focus on the factors that contributed to the rapid emergence of the crisis, ${ }^{87}$ and there are lessons for economic policy management for crisis avoidance, as well as areas where one can be critical at the margin of the stabilization program, but on balance, Koreans and the rest of the world are better off because of the fund's activities during the very difficult crisis period and its aftermath.

\section{The Indonesian Crisis}

The Korean stabilization program is of course of interest in itself; it is also of interest in analyzing the components of a Fund stabilization program and the reasons for them in light of conditions at the beginning of the crisis. By contrast, the Indonesian case is of more interest in understanding how political conditions or decisions can thwart an IMF program. I therefore very briefly sketch the background to the Indonesian crisis and the original Fund program, focusing instead on the factors that contributed to Indonesia's relatively poor performance after the initial crisis and Fund program.

\section{Background}

Indonesia had also experienced rapid growth over the preceding several decades, averaging about 7 percent annually. Indonesia started as a very populous (with little arable land per farmer and a large population, currently over 200 million) and poor country, but living standards and other indicators of well-being had risen markedly for most of the population, including that majority who were employed in agriculture. Indonesia's growth differed from that of the East Asian "tigers," however, in a number of respects. Growth of industry was spurred to a large extent by the internal market and had not been accompanied by a rapid growth of new manufacturing activity destined for exports; indeed, foreign exchange earnings to support growth originated largely in primary commodities - oil exports had accounted for more than half of foreign exchange earnings until the mid-1980s, when the price of oil fell sharply; agricultural commodity ex-

87. One can also raise issues about the incentives for foreign lending to emerging markets and ways that there might be incentives for a better balance between different forms of capital inflow. 
ports were also important. Protection against foreign imports had remained relatively high, and many new projects (such as a national car plant; there were even plans to expand the uneconomic airplane factory to produce jets) were anticipated as import substitution ventures. Many viewed the Indonesian policymakers as schizophrenic between reliance on markets (and therefore presumably on growth of exports of industries with large inputs of unskilled labor) and retaining governmental controls and ownership over industry in order to develop high-technology import-substitution industries. ${ }^{88}$

Nonetheless, growth of agricultural output and productivity had been quite rapid, and rural standards of living, literacy rates, and health and nutrition indicators had risen significantly. The fraction of people living below the poverty line had been greatly reduced.

Hence, Indonesia was regarded as an economic success story, although visibility in the international economy was well below that of the East Asian tigers with their reliance upon manufactured exports and development of international markets for their output. Key differences were that living standards remained much lower than in East Asia, and politics were more suspect, especially after Korea moved toward more representative government in the mid-1980s, with Taiwan following suit.

President Sukarno, the independence leader and national hero, was in office until 1966. During his presidency, inflation had reached the thousands of percentage points annually, exports had dropped dramatically, and living standards had clearly not risen, although statistics were sparse and unreliable.

In 1966, Sukarno was overthrown in a bloody revolution, ${ }^{89}$ and a general, Suharto, took power. He remained in office until early 1998. During his tenure, economic growth was rapid, as was already mentioned, and the Indonesian government was generally regarded as having done well in its economic policies, both for growth and for poverty alleviation. However, it was also widely recognized that President Suharto was the country's ruler, that his friends and cronies were benefiting enormously from the regime, ${ }^{90}$ and that opposition was not tolerated. As his tenure in office got longer and as he aged, the regime appeared increasingly oppressive, and questions about succession were more pressing. ${ }^{11}$

88. See, for example, Wall Street Journal, 25 March 1993, A8: "Economic Roads: Indonesia is Divided on Whether to Compete on Low Labor Costs or Try High Tech."

89. The extreme violence in 1966 is one of the bases for nervousness about political instability in Indonesia.

90. See The Economist, 17 November 1990, 37. The subheading for the article read "The world's fifth most populous country may be on its way to producing another of those famous Asian economic miracles. Will politics ruin it?"

91. I was at a luncheon of bankers in Melbourne when the Indonesian rupiah was depreciating sharply. The Indonesian economy was the subject of discussion. One of the bankers present commented that he traveled all over the world for his bank and that he had visited Indonesia the preceding July. It was, he reported, the only country he had visited on business in which the first thing he heard about was the evacuation plans in the event of a political uprising. 
The early 1990s were years of relatively successful growth: real GDP continued to grow at rates between 6 and 8 percent annually, inflation remained around 5 percent annually, and the government fiscal accounts were showing a small surplus. There were, however, a few worrisome signs. The current account deficit widened substantially from the $\$ 2$ to $\$ 3$ billion dollar range of the early 1990 s to $\$ 6.4$ billion in $1995, \$ 7.3$ billion in 1996 , and $\$ 4.9$ billion in 1997. Moreover, Indonesia's short-term debt had risen from $\$ 18$ billion in 1992 and 1993 to \$36 billion in 1997, while international reserves, which had equaled short-term debt in 1993, were only $\$ 20.3$ billion at the end of 1997. The proximate source of this deterioration was a very rapid growth of domestic credit, which had increased by 21-22 percent in every year after 1993, and which then rose by 25 percent in 1997. It was well, but not officially, known that much bank credit was destined for the relatives and friends of the president and that many loans were on nonperforming status, or were at best "evergreen," in that additional credit was extended to enable the payment of debt-servicing obligations.

An election was scheduled for early 1998, and there was considerable speculation as to whether or not Suharto would run for another term in office. However, in the summer of 1997, capital flight began from Indonesia, and the rupiah began depreciating rapidly. The exchange rate had been 2,200 Rp per U.S. dollar at the end of 1994, and 2,380 Rp per dollar at the end of 1996. Even at the end of June 1997, it was 2,450. Then the rapid slide began. By the end of September, it was 4,471; by the end of December 6,274, reaching over 17,000 at its peak, and still 14,900 per dollar at the end of June 1998.

Of the various countries that were severely affected by the Asian financial crisis, it is probably Indonesia that caught people most by surprise. ${ }^{92}$ In part, this was because of the relatively good economic performance of earlier years and, probably, a belief that the economic policies underlying this performance would continue independently of political events. Moreover, the Indonesian rupiah did not appear to be overvalued. Four sets of estimates have been made of the degree of real overvaluation of various Asian countries as of late 1996 or early 1997 . One found the rupiah to have been undervalued, whereas the other three estimated overvaluation in the range of 4.2 to 9.6 percent. ${ }^{93}$ Indonesia's incremental capital-output ratio remained at around 4 during the mid-1990s, while those of the other Asian countries were rising. Finally, Indonesian exports had continued growing reasonably rapidly - over 9 percent from the second half of 1995 to the second half of 1996 - at a time when export growth in the rest of the region (except the Philippines) had been flagging. Hence, although observers had

92. To be sure, there were runs on the Hong Kong stock exchange and to some extent on the Taiwanese dollar and the Singapore dollar. In these instances, however, defenses were successful and the impact was far smaller than in Thailand, Korea, and Indonesia.

93. Estimates for the other Asian countries also indicated little evidence of overvaluation, with the largest estimates being for the Philippines. See Berg (1999, 8), table 2. 
long recognized that Indonesia's political situation was potentially more volatile than that of the other rapidly growing Asian economies, there was less short-term concern about economic indicators.

However, the Indonesian banking system appears to have been much weaker than was generally appreciated. The official estimate of the percentage of NPLs in the banking system prior to the crisis, 8.8 percent for $1996,{ }^{94}$ was the highest in the region (Thailand's official estimate was 7.7 percent and Korea's 0.8 percent). However, JPMorgan and Goldman Sachs estimated actual NPLs as a share of total loans in 1998, and also the share at the peak of the crisis: their estimates were 11.0 and 9.0 percent respectively for Indonesia's total NPLs in 1998, and 30 to more than 40 percent at the peak of the crisis. These, too, were high relative even to other Asian countries. ${ }^{95}$

The corporate debt-equity ratio was put at 200 percent by 1996, and the estimated return on assets 4.7 percent. Thus, the financial sector was highly vulnerable and weak prior to the attack on the currency. When that attack came, the high ratio of short-term debt to international reserves was the proximate cause, but the weakness of the financial system clearly intensified it. There was no formal deposit insurance in Indonesia. ${ }^{96}$ Once the closure of some insolvent financial institutions was announced, depositors questioned the dependability of other banks, and some fled to foreign currency rather than to the sounder domestic banks. ${ }^{97}$

\section{The Crisis}

The Indonesian rupiah began to depreciate in mid-1997, after the onset of the Thai crisis. Capital flight, if anything, intensified after that, even after the first IMF program was announced and begun early in November..$^{98}$ A key problem was that, once the downslide began, political instability followed. As already mentioned, there had been questions about the forthcoming election and whether President Suharto would run again early in

94. Data on Asian financial indicators of vulnerability prior to the crisis are from Berg $(1999,8)$, table 2 , which seems to be as comparable a set of estimates across countries as is available.

95. Both sources put Korea's and Thailand's actual NPLs in 1998 above those of Indonesia in 1998, but Indonesia was still higher at the peak of the crisis by their estimates. It should be noted that the estimates for the Philippines were far below those of other Asian countries, which may explain why the Philippines was able to avoid the severe downturn that affected other Asian countries.

96. However, several banks had been closed earlier and small depositors had been compensated by the government.

97. Berg $(1999,23)$ points out that "After the announcement of the program at the end of October, foreign loans continued to be withdrawn. The exchange rate stayed reasonably stable until early December, when rumors of president Suharto's ill health ... precipitated a sharp decline in the rupiah. Rollover rates on external credits fell to very low levels and fears of imminent default intensified."

98. The first LOI is dated 31 October 1997. All references to LOIs are referred to by dates. They may be found at [http://www.imf.org/external/country/IND/index.htm]. 
1998 even before the beginning of the crisis. Indeed, as late as December, the rupiah fell, partly due to the rumor that the president's health had deteriorated and that he would not seek reelection. ${ }^{99}$ In the event, the economic downturn led to intensified political opposition, and President Suharto stepped down and was succeeded by one of his allies, President Habibie. Then, after elections were held in the middle of 1998 (for Parliament), a coalition government led by President Abdurrahman Wahid came into office. Some of the government's primary concerns were political, ${ }^{100}$ and the problems of the economy seem to have been underestimated or at least not really fully understood by the leaders of the new government.

Either way, from October 1997 onward, political considerations dominated and led to considerable uncertainty as to what actions would be taken by the relevant economic officials; even when commitments were made, it was not apparent whether they would be carried out. This pattern started even under President Suharto, who declared in January 1998 that he would not necessarily follow IMF advice (despite the LOI of November). That episode ended with the famous photo of the IMF's managing director, arms folded, looking on as Suharto finally signed another agreement.

This state of things led to a number of renegotiations, cancellations of old agreements, signing of new ones, delays in approving second tranches, and so on. There were LOIs at frequent intervals; almost all restated earlier programs or had more urgent calls for actions that had been agreed upon in them. ${ }^{101}$ The 15 January 1998 LOI, for example, set new and looser fiscal targets (in light of the severe deterioration of the Indonesian economy); the LOI of 19 October 1998 enumerated a large number of targets and set new dates for actions that had not been taken in accordance with the timetables in previous LOIs. ${ }^{102}$ In January 2000, the earlier extended facility (of $25 \mathrm{Au}-$ gust 1998) was canceled and a new extended arrangement entered into with the new government in place.

One of the manifestations of political instability was the apparent inability of the government itself to agree on a course of action. Announcements

99. Given President Suharto's age, observers were also keenly interested in his choice for a vice-presidential candidate, because his term of office if reelected would have been six years.

100. Chief among these was the role of the military. The president seems to have focused on this issue and was able to reduce the influence and power of the military significantly during the first part of 2000 .

101. See Goldstein (chap. 5 in this volume) for further discussion of some of the conditions.

102. These included such items as introducing a law in Parliament to give Bank Indonesia autonomy; earlier LOIs had targeted this for 30 September 1998; in the October LOI, it was reported as being "in preparation." Likewise, there had been an intent to review the portfolios and finances of all the banks held by the Indonesian Bank Reconstruction Authority (IBRA), which had assumed control of the banks by 30 August 1998, and it was reported that twentyseven banks had been reviewed, with the rest (twenty-seven) to be completed by November 15 . A commitment to remove restrictions on debt-equity conversions - essential for corporate financial restructuring - had been made for 30 September 1998 and was reported in the LOI as "expected soon." 
were repeatedly reversed, decisions taken were amended or not implemented, and inaction appeared to rule. Even as this paper was being written, the newly installed economy minister (who replaced his predecessor in order to bring "leadership" to the economics team) announced his open disagreement with the finance minister over the future of Bank Rakyat Indonesia. ${ }^{103}$

The decline in Indonesia's real GDP in 1998 was the severest of the crisis countries: it is recorded to have fallen by 13.7 percent, and preliminary estimates indicate a further drop of 0.8 percent in 1999. This compares with Thailand - the next hardest hit - which saw a decline in real GDP of 9.4 percent in 1998 and estimated growth in 1999 of 2.5 percent. Estimates for real GDP growth in Indonesia in 2000 center on 2-4 percent, which would not begin to reattain the precrisis level.

\section{Evaluation of the Program}

In an important sense, Indonesian economic growth has not resumed. The forecast growth in 2000 is expected to originate mostly in agriculture and other informal activities, and it reflects primarily a larger number of people in those activities. The important question is: what has gone wrong?

In a number of regards, the Indonesian situation as of mid-1997 appears not to have been dissimilar to that confronting Korea: each had political uncertainty (although Korea's election was sooner and it was quickly resolved); each had a high ratio of short-term foreign debt to international reserves; and each had a weak domestic banking system. Moreover, the initial IMF responses look similar. In both instances, programs called for financial restructuring and supporting measures for it as well as initial tightening of monetary and fiscal policy, ${ }^{104}$ and they were implemented only after the currency had depreciated markedly.

The first difference between Korea and Indonesia seems to lie in the immediate aftermath. Neither Fund program provided (or could have provided) sufficient resources to enable private creditors to have been repaid: there had to be some debt rollover in addition to the support from the international community. In Korea's case, rollover of private-sector debt and the stretching-out of maturities started almost immediately with the restructuring of bank debt late in December, and \$22 billion more was rolled over into medium-term debt in April 1999 (see Berg 1999, 21). By contrast,

103. Indonesian Observer, 13 September 2000. See also the editorial by Sadli, in Bulletin Kadin, September 2000, titled "Muddling Through of Economic Recovery Continuing, Amidst Political Uncertainties." As this paper was being revised in November 2000, Bank Indonesia officials were announcing that they could maintain monetary and exchange rate policies despite the resignation of many of the board members (Jakarta Post, 23 November 2000).

104. The Fund's later review of the programs in the crisis countries defended the initial monetary and fiscal stances in each country as set forth in the LOIs but recognized that relaxation of the fiscal stance might have come sooner. See the press conference of Jack Boorman, 19 January 1999, [http://www.imf.org/external/np/tr/1999/tr990120.htm]. 
in Indonesia's case, the capital outflow did not stop. Moreover, private firms and banks holding foreign currency-denominated debt found themselves with rupiah-denominated obligations increased by a considerably greater multiple than in Korea because of the larger proportionate rupiah depreciation. The already weak financial system was in imminent danger of collapse.

The government of Indonesia did take over the banks and founded the Indonesian Bank Restructuring Agency (IBRA) to undertake restructuring. However, IBRA was very slow to commence work, and a year after its inauguration it had done very little. Moreover, IBRA compensated banks for the loans it assumed with nonnegotiable government bonds. Much as some sort of takeover was probably in order, banks could not and cannot (since they still hold them) lend nonnegotiable instruments. There was doubt about the soundness of the banks that were still functioning; IBRA was not recapitalizing and restructuring the banks, and the banks were not lending. In the words of Al Harberger in December 1998, fourteen months after the crisis had begun:

At some point in time during the early months of the crisis, the Indonesian commercial banks, beset by demand from their own creditors, virtually shut their "new loans" window. Their determination was to collect on their "old loans" to the extent that these were amortized, and then to use the proceeds either to pay their own creditors or to strengthen their very precarious liquidity positions. The response of the commercial banks' customers to this new policy was simply to stop making amortization payments on their debts to the banks. Some customers continued to pay interest, others did not. Of those debtor companies that paid neither interest nor amortization, some were solvent and able to pay, simply choosing not to pay under the special circumstances of the moment. Others were truly unable to pay; their loans would be "bad loans" under any circumstances. Unfortunately it was not easy to discriminate among the non-payers, so that one did not have a clear idea of how many of them were in one category and how many in the other.

The situation of a wholesale "borrowers' strike" against paying off existing loans came as something new to me. It adds new complications to the problem of bailing out the banks, and may greatly magnify the cost that ultimately has to be borne by the taxpayers. (Harberger 1999, 60-61)

Failure of IBRA to act more quickly and decisively and the failure of the domestic financial system explains much of the continuing difficulties of Indonesia. Those difficulties, in turn, are in large part a reflection of the political situation and its uncertainties.

The question arises, therefore, as to (a) whether the Fund should have initiated a program in the first place and (b) once it had done so and the authorities were moving slowly, whether it should have continued in its support. The first question is by far the easier. Clearly, the political events that 
transpired once the Indonesian crisis was under way could not have been anticipated. The Indonesian situation was not that dissimilar to those in the other Asian countries, ${ }^{105}$ and uncertainties appeared to be no greater, and possibly even less, than those in Korea. Moreover, it is even conceivable that had the Fund program worked initially as well in Indonesia as it did in Korea, the political difficulties that transpired during the winter of 1998 might have been postponed, and an upturn might have taken place. Perhaps most telling of all, however, there was, as stated by Berg, an "imminent danger" of the complete collapse of the Indonesian financial system, and it seems a straightforward conclusion that anything that brought about a significantly positive probability that that eventuality would be averted was a worthwhile proposition. Moreover, Indonesia is a sufficiently large and strategically located country that many of the Fund's largest shareholders were determined that the Fund should act. If it is believed the IMF should not have done so, criticism should be directed at the large industrial countries that insisted on support for Indonesia.

The inability of the Indonesians to carry out commitments, even when backed by Fund pressure, that were obviously essential to the resolution of the crisis suggests that many of the secondary conditions set forth in the LOIs were well warranted. Indeed, much of the detail included in the successive LOIs was there precisely because steps earlier promised had not been taken. Clearly, measures to restructure the finances of the banks and the corporate sector had to be included as part of the program, ${ }^{106}$ and failure to act on these matters evidently delayed recovery.

The issue then is whether the IMF should lend at all unless these measures are undertaken. To the extent that Fund conditionality on these issues increased the likelihood of their implementation or accelerated the rate at which they were implemented, a strong case can be made for their inclusion;

105. There is also an issue, not discussed here, that was raised at that time and that supports the Fund's actions. That is, there was concern about "contagion" from country to country during the crisis. Indeed, there have been two views of the Asian crisis, one focusing on fundamentals, and the other on "irrational markets and contagion." Although it is clear that creditors, when surprised in one situation, look around to ascertain their vulnerability to similar situations elsewhere, the prevailing view of the Asian crisis seems to have swung more and more toward fundamentals as more and more evidence emerges as to the weak and weakening states of the domestic financial systems in the crisis countries in 1996 and 1997.

106. There were conditions such as that calling for the end to the government's clove monopoly that, it can be argued, while desirable, were not essential to the program and probably should not have been imposed on a government whose implementation capacity was in any event weak. Another condition called for reduced tariffs, which was arguably defensible: The ideal time to reduce import duties is when devaluation is occurring, because it minimizes the costs to the domestic economy and at the same time cuts the inflationary pressure of the devaluation. In Indonesia's case, an argument can also be made that the country had probably exhausted its potential for growth through import substitution and that resumption of growth could not occur at anything like the earlier rates unless such a measure was taken. Careful reading of the conditions in the LOIs for Indonesia suggests that there were a few, but not very many, conditions imposed that could not be justified. 
an argument against most of these conditions that were essential to financial restructuring would have to hold either that no loan should have been forthcoming until the conditions were met prior to the loan or that the Fund's imposition of conditions was counterproductive.

The second question - whether Fund support should have continued when implementation was so slow and so weak - is more difficult. The case for continued lending is probably best couched in consideration of the alternative: what would have happened, given the state of Indonesian politics, had the Fund withdrawn its support? ${ }^{107}$ Given the inability of Indonesia to attract private capital in any event, it is almost certain that such a move would have triggered further capital outflows, further weakening the fragile financial system, and reducing real GDP even further. Conjectures as to what the political responses might have been are well beyond the scope of this paper, but it seems likely that the political consequences would have been sufficiently grave that a decision on more than postponement of a tranche would almost certainly have required the approval of the major shareholders in the Fund. As already noted, it is doubtful whether such approval would have been forthcoming.

As of late 2000, the Indonesian economy had still not achieved a situation in which growth could resume and normal capital flows could replace official finance. Finding fault with the Fund program, on that account, however, requires the further step of assuming that there was an alternative program that either would have resulted in a different political evolution of the country or would have worked even in the absence of better implementation on the part of the government. Those believing that the IMF programs were inappropriate should be asked to specify an alternative scenario: it is not evident that there is one.

\subsubsection{Contrasts between Korea and Indonesia and Other Countries}

Thailand's crisis had a great deal in common with those in Korea and Indonesia. Thailand had a long history of rapid economic growth based on a reasonably open economy and export growth at a fixed nominal exchange rate. However, the financial sector was very weak and deteriorating. In the mid-1990s, a real estate boom was accompanied by rapid expansion of bank credit (averaging 37 percent per year from 1992 to 1996), in turn financed by capital inflows. Nonperforming loans prior to the crisis are estimated to have been between 17 and 18 percent of all bank loans outstanding. Because many were secured by real estate as collateral, Thailand was highly vulnerable to any decline in real estate prices. Between 1991 and

107. On several occasions, disbursement of later tranches of Fund support were delayed pending improved implementation. This happened, for example, in April 2000. The Fund staff obviously had to make a judgment call as to how much action they would insist upon as a condition for additional support. 
1996, in addition, the debt-equity ratio of Thailand's corporate sector had increased from 170 to 340 percent, which was the second highest among the crisis countries.

In the case of Thailand, IMF staff were reported to have been urging the Thai government to alter the exchange rate or the exchange rate regime for at least a year prior to the crisis. The current account deficit had averaged over 6 percent of GDP in the 1991-95 period and stood at 7.9 percent of GDP in 1996. Short-term external debt at the end of 1996 was almost exactly equal to reserves.

When the crisis unfolded, capital outflows from Thailand were a key culprit. Initially, several banks were closed, and immediate action was taken to begin to restore the financial system. New money associated with the inauguration of the IMF program and exchange rate change (with the rate floating) was sufficient to stem the capital outflow. ${ }^{108}$ The Thai government appears to have followed the fund programs fairly faithfully, and Thailand's recovery has been second only to Korea's among the crisis countries. As in the other crisis countries, the fiscal stance was loosened as the severity of the crisis became evident.

An interesting contrast is with that of a noncrisis country: the Philippines. By most measures of the performance of the foreign sector, the Philippine economy had the most troublesome situation going into the crisis period. The country had had a lower overall rate of economic growth in the 1990s than any of the crisis countries. Its real exchange rate is estimated to have appreciated markedly from 1991 to 1995; the current account was in increasing deficit, reaching 4.7 percent of GDP in 1996 and 5.3 percent of GDP in 1997. Moreover, the government was incurring small fiscal deficits, and public debt was a higher percentage of GDP in 1997 than in any of the crisis countries.

However, its financial sector appears to have been considerably stronger than that of the crisis countries. JPMorgan and Goldman Sachs, respectively, estimate actual NPLs in the banking system in 1998 as 5.5 and 3.0 percent of outstanding loans, and the peak after the crisis was proportionately much lower than that of any of the crisis countries. The corporate sector's debt-equity ratio was put at 160 , somewhat lower than that of the other crisis countries.

These differences are striking: the Philippines' external sector was in more severe disequilibrium than that of the crisis countries, but its financial sector was in considerably better shape. The Philippines' nominal exchange rate depreciated 32.2 percent. However, the fact that its banking system was

108. Berg (1999) credits the stemming of capital flight to the Fund program and the fact that "foreign banks based in Thailand accounted for more than half of Thailand's private external debt maturing in 1998. These banks, largely Japanese institutions borrowing from their own headquarters, were willing to agree to maintain their exposure" (25). 
sound permitted it to lower the nominal interest rate in 1998, and real GDP fell by 0.5 percent - a much smaller magnitude than any of the other crisis countries. ${ }^{109}$

Based on other corroborating evidence (the ease of Brazil's recovery from the real crisis in the context of a relatively sound banking system) as well, the conclusion seems inescapable that the negative impact on real GDP and an economy of a financial crisis combined with an external crisis is much greater than the sum of the negative impacts of two separate crises: each feeds upon the other. It also seems evident that restructuring the financial sector-or at least putting in motion credible policies that will insure the rapid restructuring - is essential to the resolution of a crisis triggered by capital outflows. Delay does not appear to ease the negative effects but to prolong them and perhaps even to intensify them.

The international economy can be, and is being, restructured in ways that make a crisis, either financial or foreign exchange, less likely. Floating exchange rates, altered BIS capital adequacy rules so that short-term debt is not preferred on the part of lenders, and various steps that have been taken and are now being contemplated to strengthen financial systems and to redress the imbalances between the attractiveness of short-term lending and other forms of capital inflow will all contribute.

However, crises there will surely be. Lessons from the Asian crisis will certainly enable all analysts to appreciate the interactions between financial and foreign variables and their crucial roles in determining vulnerability for crisis and its aftermath. However, especially in a world in which capital outflows can magnify quickly, an institution such as the IMF seems absolutely essential for ensuring the world's ability to react in a timely fashion. Moreover, as long as there are weak financial systems negatively affected by exchange rate movements or capital outflows, it will continue to be necessary for the IMF to address financial restructuring as well as exchange rate issues.

\section{References}

Behrman, Jere. 1976. Foreign trade regimes and economic development: Chile. New York: Columbia University Press.

Berg, Andrew. 1999. The Asia crisis: Causes, policy responses, and outcomes. IMF Working Paper no. WP/99/138. Washington, D.C.: International Monetary Fund, October.

Boughton, James M. 1999. From Suez to Tequila: The IMF as crisis manager. Economic Journal 110 (460): 273-91.

109. The shift in the Philippines' current account balance in 1998 was 6.7 percent of GDP, contrasted with 7.2 percent in Indonesia, 16.9 percent in Korea, and 20.3 percent in Thailand. 
Cho, Dongchul, and Kenneth D. West. 1999. The effect of monetary policy in exchange rate stabilization in post-crisis Korea. Paper presented at the Korea Development Institute conference on The Korean Crisis: Before and After. 15 October, Seoul, Korea.

Cline, William R., and Sidney Weintraub, eds. 1981. Economic stabilization in developing countries. Washington, D.C.: Brookings Institution.

Cooper, Richard N. 1971. An assessment of currency devaluation in developing countries. In Government and economic development, ed. Gustav Ranis, 472-513. New Haven, Conn.: Yale University Press.

Edwards, Sebastian. 1989. Real exchange rates, devaluation, and adjustment. Cambridge: MIT Press.

Ergin, Evren. 1999. Timing of IMF programs. Ph.D. diss., Stanford University.

Feldstein, Martin. 1998. Refocusing the IMF. Foreign Affairs 77 (March/April): 20 33.

Frank, Charles R. Jr., Kwang Suk Kim, and Larry Westphal. 1975. Foreign trade regimes and economic development: South Korea. New York: Columbia University Press.

Furman, Jason, and Joseph E. Stiglitz. 1998. Economic crises: Evidence and insights from East Asia. Brookings Papers on Economic Activity, Issue no. 2:1-114. Washington, D.C.: Brookings Institution.

Hahm, Joon-Ho, and Frederic S. Mishkin. 1999. Causes of the Korean financial crisis: Lessons for policy. In The Korean crisis: Before and after, Korea Development Institute, 55-144. Seoul: Korean Development Institute.

Harberger, Arnold C. 1999. The Indonesian crisis revisited. University of California, Los Angeles. Mimeograph, December.

Hong, Wontack. 1981. Export promotion and employment growth in South Korea. In Trade and employment in developing countries, vol. 1: Individual studies, ed. Anne O. Krueger, Hal B. Lary, Terry Monson, and Narongchai Akrasanee, 34191. Chicago: University of Chicago Press.

International Monetary Fund (IMF). 1995. International capital markets: Developments, prospects, and policy issues. Washington, D.C.: IMF.

. 1997. Request for standby, 3 December.

James, Harold. 1996. International monetary cooperation since Bretton Woods. New York: Oxford University Press.

Krueger, Anne O. 1978. Foreign trade regimes and economic development: Liberalization attempts and consequences. Lexington, Mass.: Ballinger Press.

. 1979. The developmental role of the foreign sector and aid. Harvard University Press Studies in the Modernization of the Republic of Korea: 1948-1975. Cambridge, Mass.: Harvard University Press.

. 1999. The founding of the Bretton Woods institutions: A view from the 1990s. In The political economy of comparative development into the 21st century, vol. 1. ed. Gustav Ranis, Sheng-Cheng Hu, and Yun-Peng, 335-54. Cheltenham, England: Edward Elgar.

Little, I. M. D., Richard N. Cooper, W. Max Corden, and Sarath Rajapatirana. 1993. Boom, crisis, and adjustment: The macroeconomic experience of developing countries. New York: Oxford University Press.

Organization for Economic Cooperation and Development (OECD). 1994. OECD economic surveys: Korea 1994. Paris: OECD.

Sturc, Ernest. 1968. Stabilization policies: Experience of some European countries in the 1950s. IMF Staff Papers 15 (2): 197-217.

Williamson, John, ed. 1983. IMF conditionality. Washington, D.C.: Institute for International Economics. 


\section{Stanley Fischer}

Because the discussion at the conference has focused on International Monetary Fund (IMF)-supported stabilization programs in Asia, I will start by outlining some of the lessons the IMF has drawn from the programs in Asia during 1997-98. I will then take up five general issues that arise in all IMF-supported programs: when to lend; choosing an exchange rate regime; setting fiscal and monetary policy; determining structural policy conditions; and how much to lend.

First, let us consider Asia. Jack Boorman and other IMF colleagues have written a thoughtful paper on IMF-supported programs in Thailand, Indonesia, and Korea in 1997-98 (Boorman et al. 2000). Among the key conclusions are the following:

- First, fiscal policy was too tight at the start of each program, but it was loosened rapidly (especially in Indonesia and Korea) once the extent of the economic downturns became clear.

- Second, the bank closures in Indonesia should have been more wideranging (when the sixteen banks were closed, it was known that others would have to be closed, which reduced confidence in the remaining banks) and there should have been more comprehensive guarantees for depositors (deposits in the closed banks were guaranteed up to a level that provided coverage for small depositors), to help persuade them to leave their deposits in the banks that remained open.

- Third, the Fund was right to put the focus of structural conditionality on financial system and corporate debt restructuring, problems that lay at the heart of the crisis. However, there may well have been too many structural policy conditions at the margins of the Fund's areas of central competence and interest. In some cases, particularly that of Indonesia, this conditionality was included to try to improve governance.

- Fourth, our advice on monetary policy was broadly correct. If monetary policy mistakes were made in Indonesia, they were because policy was too loose, not too tight.

- The programs succeeded when they were implemented resolutely and consistently. In all three cases, this took a change of government. Indonesia was a special case. The course of the crisis was tied up with the uncertainties surrounding the Suharto succession. We believed-and were assured by important Asians - that the key to restoring market confidence was to get the president's public support for the economic program. However, it seemed that when he did express support for the program-for policies that were at odds with much of what he had been doing for decades - the markets simply took this as a signal that 
his time was running out, and they had no idea what would follow his departure.

Now let me turn to some more general issues.

\section{When to Lend}

In an ideal world, the Fund would get involved with a country early in its difficulties, when there is still time to stop the drama turning into a crisis. However, this is easier said than done. For one thing, the IMF cannot force a country to have a program. The country has to ask, and then the program has to have a reasonable chance of success.

It is clear from our Article IV consultations that we were warning about financial weaknesses in Asia long before the crises came to a head. In Indonesia, we were approached by technocrats in the government in August and September 1997 who were well aware of many of the problems in the banking sector and of what needed to be done to fix them. The president was not on board, however, and we could not move to a program because we had no confidence that the necessary measures would be carried out.

We are often urged to support a particular policymaker, or group of policymakers, because they offer the best - sometimes, we are told, the onlyhope of getting a country out of its economic mess. That may well be so, and in many cases our support makes it more likely that the right things will happen. However, we have to be realistic. We cannot ask our executive board to commit the Fund's resources to support even the best-intentioned of reformers if the program does not have a reasonable chance of success.

This is a tough call to make. The best programs are those to which the authorities, and ideally the society more widely, are committed-programs owned by the country. For instance, in the program with Colombia that began at the end of 1999, we were confident of the ability and commitment of the Colombian policymakers to the principles and design of the program, and the political support they had, even though the difficult conditions in Colombia meant their task would not be easy.

Cases in which the international community is in effect supporting a particular reformist policy line, which is opposed by important and powerful domestic factions, are much more difficult. However, if we took a purist approach and never supported any program in which ownership is less than complete, then we would not support a significant number of programs that succeed. In many such cases, this is a risk that the international community is probably right to take.

\section{Choosing an Exchange Rate Regime}

The crises of the last few years demonstrate that countries open to international capital flows are wise to have either floating exchange rates or, de- 
pending on their histories, hard pegs, by which I mean dollarization, a currency board, or membership of a currency union. ${ }^{1}$ Intermediate regimesadjustable pegs, crawls, and narrow bands - have generally proven unsustainable.

I do not mean by a floating rate regime one in which monetary policy is completely indifferent to the level of the exchange rate. Policymakers can influence the exchange rate through monetary policy actions or occasional intervention. What they should not do is allow the defense of a particular value for the exchange rate to become the central plank of the country's economic policy, unless that commitment is enshrined in some form of hard peg.

In accordance with the Articles of Agreement, which leave the choice of its exchange rate system to each country, the IMF generally avoids being doctrinaire on the exchange rate regime when deciding whether to support a country's program. We have taken different approaches in different situations. In Ecuador, early in 2000, we supported dollarization after the event, even though we would not have recommended it beforehand. In Colombia, a few months earlier, we did insist on a move to a flexible rate, because the currency had been pushing against the bottom of its band for some time and the regime was clearly unsustainable. In Turkey, we supported a crawling peg to stabilize triple-digit inflation to begin with, but with an exit strategy to a float built in, a strategy that did not succeed.

If the Fund is convinced - as it was in Colombia - that a given regime is unsustainable, then it would be irresponsible to support a program that incorporates that regime. However, where the outlook is less clear-as it was, for instance, in the case of the Brazilian peg in October 1998 - we have generally given the country the benefit of the doubt. This has been controversial, for there are always some who are convinced that the currency is overvalued and should not be defended. In giving the country the benefit of the doubt, we are deeply aware that we are not the policymakers directly concerned and responsible to the voters in that country, and that responsibility for a decision on a change in exchange rate or exchange rate regime, which may have massively adverse consequences, must rest with those who will carry it out.

Exit from a pegged exchange rate system is always difficult. When the going is good and the peg is strong, the country sees no reason to change the system. However, if the peg is under pressure, the policymakers will insist on defending it, for fear of the consequences of devaluation. And sometimes - for instance, in the case of Jordan, which has defended its peg over the period since 1996 - they do very well this way over sustained periods. In such cases, the Fund generally tries to persuade the country gradually to allow more flexibility in the rate.

1. This theme is developed in more detail in Fischer (2001). 


\section{Setting Fiscal and Monetary Policy}

Three interrelated factors help determine the required degree of fiscal adjustment: the sources and extent of financing for the budget deficit; the sources and extent of financing for the balance of payments; and debt dynamics. In the Brazilian program formulated in early 1999, after the devaluation, the debt dynamics were the critical factor. The debt-GDP ratio was 33 percent at the start of the plan real in 1994; it was 47 percent and rising in early 1999. The question was: how much fiscal tightening was needed to turn this trend around, given cautious assumptions on the behavior of real interest rates?

In Thailand we called initially for fiscal tightening for three reasons: because the balance-of-payments deficit had been large before the program; because the implicit liabilities and debt that would be created by financial restructuring had to be dealt with; and because we believed that would strengthen market confidence. In Indonesia and Korea, the tightening was motivated by the last two factors. These were legitimate concerns, although it soon became clear that policy was initially set too tight, and fiscal policy was eased.

In setting monetary policy within a program, the concern is to avoid generating too much inflation. Typically, performance criteria for monetary policy in IMF programs are set in terms of specific quantitative limits on certain monetary variables, usually a floor for net international reserves and a ceiling on net domestic assets of the central bank. There are interesting analytical questions about how best to adapt this time-tested framework to countries where monetary policy is set in terms of an inflation target. In a case like that of Brazil, where there is confidence in the people carrying out the inflation-targeting framework, getting the technicalities right may not be terribly important. However, there will be other countries where the precise specification of the monetary policy conditions is much more important.

\section{Determining Structural Policy Conditions}

Structural policies rightly come within the purview of IMF-supported programs when tackling them is essential to solving the country's macroeconomic problems. The scope and detail required will therefore vary from country to country. In our 1999 program with Ecuador, for example, privatization was needed not only for efficiency reasons but also because the country needed the privatization revenues to reduce its debt significantly. Banking-sector problems are often the source of structural conditions. In some transition economies, restructuring of the energy sector is needed for both balance of payments and domestic macroeconomic reasons.

The scope and detail of structural policy conditions in IMF programs has increased in recent years, in part because there is greater recognition now of the importance of structural policies in creating the conditions for 
macroeconomic stability and strong growth. However, there are also two major concerns: first, that the Fund has been moving outside its areas of concentration and expertise; and, second, that demanding too many conditions may be an infringement of national sovereignty that risks undermining the authorities' commitment to the program. In response, the Fund is streamlining structural conditionality.

One of the hardest areas in which to do this is governance. It is an unavoidable fact that if the international community wants to help countries in trouble, then it will be hard to sustain public support for this activity if people believe that the money we lend ends up in the hands of crooks. So governance - in the sense of corruption - issues inevitably have to be addressed.

This is a defensive reason for tackling governance problems. However, doing so is also good for the country concerned and its citizens (it also happens, in my view, to be the right thing to do). Indeed, the IMF frequently finds civil society in borrowing countries strongly supportive of anticorruption measures in IMF programs in their country. How far you go in each case is a different matter. Whether we should have confronted the clove and plywood monopolies in Indonesia is a reasonable matter for debate. However, some measures were undoubtedly necessary to begin changing the ways in which business was being done in Indonesia, if the investment climate and the basis for investment decisions in Indonesia were to change.

In determining structural policy conditions, we also have to ask how we can cooperate most effectively with other agencies to deliver the international community's objectives. Many necessary structural reforms are the primary responsibility of the World Bank, for example, the creation of social safety nets, or privatizations. Including these elements in a program helps ensure that they get done, and in the past we often included them at the request of the World Bank for that reason. We are now examining, with the World Bank, whether there are better ways of achieving the desired outcome.

\section{Deciding How Much to Lend}

In deciding how much the Fund should lend, it is conceptually important to distinguish between liquidity and solvency crises - a distinction easier to make in theory than in practice. Essentially, we need to decide whether a country's balance-of-payments position is sustainable in the medium term. If it is not sustainable, then it will be necessary to restructure its debts. If it is sustainable, then we might be prepared to lend big sums to help countries through the crisis. That is the appropriate solution to a liquidity crisis. Other considerations of course come into play in deciding when "big" becomes "too big," including the perceived risk of moral hazard. These issues are hard to judge in the abstract and have to be dealt with largely crisis-bycrisis. 
One clear lesson from the crises in Asia and subsequently is that the days of smoke-and-mirrors lending are gone. If the international community is going to promise money, then it had better be there and it had better be seen to be there. It also needs to be available quickly. These lessons from some of the Asian programs were applied successfully to the Brazilian program that began in 1998.

\section{References}

Boorman, Jack, Timothy Lane, Marianne Schulze-Ghattas, Ates Bulir, Atish R. Ghosh, and Ham. 2000. Managing financial crises: The experience in East Asia. IMF Working Paper no. WP/00/107. Washington, D.C.: IMF.

Fischer, Stanley. 2001. Exchange rate systems: Is the bipolar view correct? Journal of Economic Perspectives 15 (2): 3-24.

\section{Jeffrey D. Sachs}

Thanks very much, Marty, and thanks for the opportunity to review this issue yet again. As you might guess, I'm going to take a bit more critical view of what's happened. I want to say at the outset that it is not in any way a personal view of any of the people involved, because there could not have been, I think, a stronger group with greater integrity than the people that led this.

I'd like to start with one general point, which also follows our discussion this morning, about the way that our profession discusses the issues that we've been exploring. I thought the discussion was fabulous, but I would have liked one sentence arching over the discussion, and that is that we cannot and should not be searching for one solution or one policy prescription that's appropriate to everybody and to all circumstances. I think the most important thing in macroeconomic policy making is to undertake what doctors call a "differential diagnosis." The symptoms of any case can suggest multiple competing explanations and interpretations. The first job is to understand which of these alternative views applies in a given historical context. Only then can the correct treatment be prescribed.

Since macroeconomic crises are very nonlinear and path-dependent processes, the detailed decisions matter a lot in determining the outcomes over the course of a couple of years. I should also add that I would have little disagreement with anything the International Monetary Fund (IMF) did in Asia if we were looking at a horizon of five to ten years. My concern is about the specifics of IMF management in the heat of the crisis. Over the horizon 
of a few years, we all believe in open markets, currency convertibility, financial-sector reform, and fiscal prudence. There are few fundamental issues at stake regarding medium-term macroeconomic management. The problem, as Keynes famously observed, lies in the short run - when the patient is very sick, and when a proper diagnosis is essential. The wrong prescription can further weaken, if not kill, the patient.

I think the origins of the Asian crisis are now fairly much accepted, and I think they could have been fairly well understood back in the middle of 1997. To refresh my mind, I went back to see what I wrote in op-eds and policy memos even before the crisis got serious in the fall of 1997. The basic problems - of overvalued currencies pegged to a strong dollar, huge shortterm capital inflows, underregulated banking sectors, and financial vulnerability as a result of all of these factors - were all rather apparent.

The real issue was, in my opinion, was how to handle events at three critical periods. First, during the summer and fall of 1997, the collapse of the Thai baht pushed the region into a period of high risk. Second, at the very end of 1997 and early 1998, the region was in fulminant financial panic, marked by the massive and intense flight of foreign and domestic capital. Third, as of mid-1998, the region needed to consider the long-term strategies for cleaning up the balance sheets and overcoming the collapse of the financial system. My quarrels with the IMF mainly involved the first two time periods.

In the summer and fall of 1997, the entire region got pulled into financial crisis following the collapse of the pegged exchange rate in Thailand. Was the crisis inevitable? Specifically, was it inevitable as of mid-1997 that the region would face a fall in gross national product (GNP) of 5 percent or more in 1998? I think that the answer is no. The steep downturn could have been avoided. There was nothing in the "fundamentals" of the productive sectors of the East Asian economies that warranted a fall in output of 5-10 percent of GNP in 1998 (especially considering trend growth rates of more than 5 percent per year in most of the region). The steep fall was the result of financial panic, and the panic, in my view, could still have been averted in mid-1997.

We now know, in retrospect, that the collapse of output was the result of a ferocious outflow of short-term capital from the region. The capital left, in my opinion, not because of fundamentals, but because of a self-fulfilling panic. Since short-term debts were so high relative to reserves, panicky short-term claimants came to believe that they needed to move their money out of Asia ahead of other short-term creditors, lest they get caught with illiquid assets when the region's foreign reserves were depleted (as of course actually happened to the slow-moving investors). This was a rational view assuming that others took the same point of view-in other words, a "rational panic," in which a nonpanic equilibrium could also have been achieved. 
If nobody had panicked, the short-term debts could have been rolled over, as usual. Maturities could have been lengthened to reduce vulnerability. The economies were strong enough over the medium term to scale back their current accounts, and export their way out of debt crisis, with moderate currency depreciations eliminating the preceding overvaluations. Instead, however, there was panic, and the banks and the government could not redeem the short-term loans being pulled. The result was a default on debt repayments and a ferocious credit squeeze.

In short, the East Asian economies were vulnerable to panic (because of high short-term debts, overvalued currencies, and weak financial sectors), but they were not fatally ill. So what pushed the economies from a moderate slowdown into a full-fledged panic? I believe that the panic was due, at least in some part, to the behavior of the IMF itself. When the baht was devalued and other neighboring countries started to face withdrawals of credit, the IMF began demanding root-and-branch reforms. The rhetoric from Washington escalated. Suddenly, the Asian economies could do no right. What had been Asian-style capitalism suddenly turned into Asianstyle cronyism. All this was fine and good, except that the rhetoric was part of the fuel of the panic itself.

There were three interlocking mistakes, in my mind. The first, and perhaps the most explosive, was the decision by the IMF, in the middle of a fragile situation, to force the widespread closure of weak financial institutions in Thailand, Indonesia, and Korea. Again, I don't think I'd have any disagreement on a three-year or five-year horizon with tightening up on financial standards, and even closing many banks, but this is a crucial matter of timing. Wisdom led the U.S. bank regulators not to close the major U.S. commercial banks in the middle and late 1980s when the banks had very weak balance sheets (following the Latin American debt crisis), or even to close Long-Term Capital Management in 1998, for fear of a major credit crunch. Yet the IMF pushed hard for massive bank closures in Asia, and this helped to instigate panic, in my opinion.

In Indonesia, which was the place I was following most closely, one economic advisory group, and I don't vouch for them, wrote on 28 October, two days before the bank closures, "Forcing problematic banks to liquidate in the midst of the ongoing monetary crisis would further deteriorate confidence in the monetary sector, and could spark a run on the banks. The government should not act hastily in forcing problem banks to liquidate. It's likely bank liquidation would be done discriminately with banks owned by politically well-connected business people escaping the ax. Such bias would cause uncertainty among people and might worsen the public's confidence in the banking industry. This would in turn start a massive bank run, where customers would move their funds to foreign banks." Regulatory forbearance makes a lot of sense when you're in such an explosive environment.

Second, I felt that the IMF was trying to prove its strength by stressing 
how much the Asian economies needed fundamental reforms. The IMF began to lecture the Asian economies incessantly about all that was wrong with crony capitalism. Deep and rapid reforms, it was argued, would restore confidence. However, this approach did the opposite, making investors feel that the sky was falling, when all that was needed was a modest 20 percent depreciation of formerly pegged exchange rates.

Third, I thought that the way that the packages were put together at the beginning added to the likelihood of panic (and said so repeatedly at the time, for whatever it's worth). The notion that raising interest rates sharply in this context, squeezing credit, closing banks, and cutting budgetary spending sharply would raise confidence rather than lowering confidence was something that I found profoundly doubtful. When the packages were introduced, they certainly did not stop the panic. This is important to understand because, again, we're not debating views on fundamentals, or whether Suharto was a creep or whether his son was a crook or anything like that. We're debating clinical approaches to an incipient (but still avoidable, perhaps) financial panic. When the packages were introduced, the currencies continued to slide, the bank run developed in Indonesia in November, and the Korean package failed to stop the flight of creditors from Korean banks in December.

The result is, in my view, a macro collapse in 1998 that was much deeper than was justified by the real economy. Moreover, I saw in many countries that the fall of output was the result of the ferocious liquidity squeeze that marked the financial panic. In Indonesia, for example, the shoe manufacturers' association came to see the government in January 1998 to complain that the industry had confirmed international orders for around $\$ 500$ million of shoe exports, but no working capital to buy the inputs needed for highly profitable exports! Thus, even in the context of an incredibly weak currency, exports were falling, not rising, because of the intensity of the financial squeeze. This is a powerful sign (among many such signs) that output fell far more than was justified by fundamental factors.

The credit squeeze might not have been fully avoidable (i.e., the panic may indeed have been unstoppable in late 1997, despite my belief that indeed it could have been avoided), but it surely did not have to be met with massive budget cutting and interest rate increases. There is the problem of the second time horizon that I mentioned at the start of my remarks, the period from the very end of 1997 to early 1998, when the panic was already fulminant. In this period, the IMF really piled on, demanding massive structural reforms while also advocating fierce fiscal austerity in the midst of a massive credit squeeze.

The IMF fiscal and monetary package certainly didn't ease the crisis. What really stopped the fierce downturn was the end of the short-term capital outflows. This occurred throughout Asia in late 1997 and until mid1998 for three reasons: some debts were finally rescheduled or rolled over 
(as in Korea just after Christmas); central banks ran out of reserves, leading to defaults by domestic banks and companies to foreign creditors; and, third, many of the short-term loans were simply repaid.

Is all well that ends well? After all, the economies have recovered. Our judgment on how things went depends on the standards that we use. I think that there has been a tremendous amount of unnecessary suffering and economic loss. The legacy of the financial panic will last for years, because governments took on enormous debt in order to bail out the collapsed financial sectors.

Final notes. First, prevention is essential. In the precrisis moment, when a spark can set off a conflagration, forbearance and subtlety, not shouting, are all really good pieces of policy wisdom. In the crisis itself, it's crucial not to overload macroeconomic austerity, not to exacerbate panic, and to understand panic as a real phenomenon, not just as a turn of phrase, but as an actual event in capital markets that squeezes real output from the supply side, not the demand side. Forcing rollovers or standstills on debt repayments should be a core part of how we handle these episodes. Finally, we had U.S. senators pressing the IMF to make sure that the Korean deal with the IMF included market-opening clauses or other specific trade measures reflecting U.S. interests rather than Korea's macroeconomic needs. We have to figure out ways to keep the IMF a truly international institution, and not a creditor institution of the major shareholders. Thanks.

\section{Discussion Summary}

Guillermo Ortiz complained about the publicity that sometimes surrounds IMF missions to crisis-afflicted countries. After the Mexican crisis, no one knew when an IMF official was in the country, he said, adding that this was very helpful. Responding to Jeffrey Sachs's comment on the need for clinical analysis of each crisis, Ortiz expressed doubt about the likely success of ex post counterfactual analysis of alternative policy responses. As an example, he recalled that interest rates rose to 80 percent in February and March of 1995. "Would 40 percent have been enough?" he asked, answering, "I really don't know." He said you have to overshoot in your policy response in the midst of a crisis, avoiding the greater danger of falling short and not reestablishing confidence.

Morris Goldstein said that an important difference between Asia and Brazil was the extent of currency mismatches - liabilities denominated in foreign currencies and assets denominated in domestic currency - on the balance sheets of banks and corporations. The devaluation in Brazil was not associated with large-scale bankruptcies. He noted various ways to 
limit the mismatch problem: moving to a floating rate (counting on currency movements to make people aware of exchange rate risk); putting a spotlight on the extent of the mismatches so that the market demands a premium for lending where such mismatches exist; and dollarization. On the question of whether large recessions could have been avoided if a different policy course had been followed, Goldstein thinks the answer is "No." If the IMF had come out and said that it was really just a liquidity crisis and there was nothing to worry about, the markets would not have been reassured, given the bad news that was coming out each day about the state of the financial systems. Lowering interest rates worked in Australia, Sweden, and the United Kingdom - but they are not emerging markets, he said.

Peter Garber commented on the use of the word "panic." What we saw was a kind of "cold panic" that followed from the way risk is managed in industrial-country banking systems, he said. Value-at-risk methods push almost automatic reductions in positions as returns become more correlated in a crisis. Managers are faced with the option of increasing the capital held against positions in emerging markets or reducing those positions. The positions are often unwound. He dislikes the word "panic" in this context because it suggests that two outcomes can occur, with psychology determining which one prevails. It is not psychology, he said, but the result of the way risk is managed.

Paul Keating highlighted how the ending of the cold war led to a major shift in the importance attached by the industrial countries to Indonesia. One implication of its fall from importance was that debt standstills were not tried and, indeed, were strongly objected to. The ultimate result was a dramatic shift in capital flows. Regarding what was needed to maintain Suharto's support for reforms, he said support was lost as the list of demands for structural reforms grew, and he blamed the IMF for saying things that undermined investor confidence in Indonesia. Stanley Fischer strongly objected to this characterization of the IMF's role, which he said reflected a common misperception in Australia. Keating went on to describe the huge political and economic difficulties that Indonesia now confronts and called for some humility on the question of how appropriate the international response to the crisis was. He said that Indonesia had a liquidity and credit crunch, adding that "countries that didn't get the IMF in, like Malaysia, did better, and this point has not gone unnoticed." Returning to the geopolitical significance of Indonesia, he said that the Asia Pacific Economic Cooperation (APEC) would not have been possible without Suharto and his government. And Keating doubts that China would be joining the World Trade Organization (WTO) if APEC did not exist. He closed by urging the IMF to focus on its core mission of dealing with balance-of-payments disequilibria- "standing up to the United States Treasury or whoever," if necessary.

Charles Dallara said that it is important to recognize that the IMF, like 
everyone else, was scrambling to understand the transmission mechanisms in the unfolding crisis. Mistakes were made, but these mistakes are related to the complexity of the underlying mechanisms. On the question of the Fund's fiscal emphasis, he agrees that too much stress was placed on correcting fiscal problems. But, again, the path to restoring confidence was unclear. He added that at this time of "noncrisis" he is actually more worried that the Fund is not putting enough emphasis on fundamental fiscal reform, such as establishing rational, broadly based tax systems.

On the question of corruption and governance, Dallara said the Fund's shareholders would not tolerate putting money into countries where there is a high probability of misappropriation. He added that the fund needs more help in grappling with governance issues, taking into account its lack of staff expertise in such areas as corporate governance. If the Fund is to avoid mission creep, he said that it is essential that the World Bank take on a larger role in these areas, adding that if the World Bank "continues to address the diagnosis and development of programs for structural reform at the pace it does today, and the pace it has for all the years I've known it, the Fund has little choice but to scramble to try to cope with these issues itself." If the Fund's shareholders want to avoid mission creep, "they have to develop a much more activist, fast-paced organization in the World Bank."

Nouriel Roubini commented on a number of issues in Jeffrey Sachs's presentation. First, he said that while most people agree that the initial fiscal policies were too tight, two caveats needed to be kept in mind: some countries (notably Russia and Brazil) did have serious fiscal problems, and the financial-sector bailouts had major fiscal implications. Second, he said that he does not agree that an easier monetary policy would have helped. Given the large amount of foreign debt on the balance sheets, and given the fact that a lower interest rate would have led to further devaluation, the balance sheet effects of a looser monetary policy "would have been disastrous." As evidence, he compared Indonesia, which he said pumped in huge amounts of liquidity to support the banking system, to Korea and Thailand, which followed a more restrictive monetary course. Third, he questioned the wisdom of substantial "forbearance" when dealing with the banks. In many cases-finance companies in Thailand, merchant banks in Korea, and so on - the institutions were insolvent rather than illiquid. This raised the traditional problem of the institutions' "gambling for redemption." Roubini added that the eventual costs are greater if you don't intervene. To avoid panic, care must be taken in closing down institutions - for example, putting in place appropriate deposit insurance - but forbearance is not a solution. Fourth, Roubini said he disagrees with those who claim that there weren't significant problems in the real economies of the Asian countries prior to the crises. In Korea, for example, seven out of the top thirty chaebol were already formally bankrupt in the middle of 1997. Finally, on the question of how to stem the outflow of capital, he expressed skepticism 
about the wisdom of debt standstills. He pointed to various unintended consequences: a "rush for the exit" when standstills are anticipated; the risk of contagion as investors fear standstills in other countries; movement down the slippery slope to exchange and capital controls; inducement to asset stripping; and costly litigation.

Larry Summers sought to correct what Jeffrey Sachs said about guaranteeing bank liabilities in Korea. He said the Korean government had given a guarantee to cover most of the liabilities during the summer of 1997 and believed it was important to stand by that guarantee. Although one can disagree about the wisdom of such a guarantee, the international community had supported the Korean government's efforts. The support was not the "craven kowtowing to international capital that Jeff suggests," he said. Summers then asked two questions.

First, was the international community right in forcing Thailand to disclose its true net reserve position in the summer of 1997 (when it had substantial forward positions that effectively depleted its foreign reserves)? Jeffrey Sachs thinks it probably was a mistake, pointing out that the markets misunderstood the disclosure. People thought $\$ 30$ billion had been lost, instead of market losses on contracts worth $\$ 30$ billion. Fischer said there was never going to be a good day to make the disclosure. "There was no good time; it was done at the least bad time," he said. On how it was presented, he thinks it might have been possible to explain it better, but they tried hard to show people the cash flow projections and to emphasize that they were not going to lose $\$ 30$ billion.

Second, Summers asked those who dislike what the Fund did in Indonesia if it should employ more or less people who think about political and governance issues. More people would allow the Fund to be more sensitive to the nuances of the situation. Fewer people would make them less involved in the set of issues that surround governance, and thus less involved in structural issues. Sachs said that adding more political experts is not desirable for the world system, given its present lack of legitimacy. He said he would rather see the institution depoliticize to become the foremost crisis prevention and crisis management tool for financial markets.

Edwin Truman said that Jeffrey Sachs's prescription, which he sees as amounting to massive forbearance, creates moral hazard on the debtors' side. He then raised the question of how vocal the IMF should be, recounting that he used to be of the view that the IMF should go quietly into a country. However, he does not think that is realistic today, now that the IMF has to explain what it is doing. He added that the IMF had used all its leverage with Thailand in advance of the crisis but was largely ignored. Indeed, Thailand devalued without going to the Fund for a program - which he dubbed the "Mexican solution" (in 1994) - which put the Fund in a difficult situation. He concluded by saying that Fund officials "should be judicious, but the notion that they should be absolutely quiet seems to me to be just unrealistic." 
Anne O. Krueger recounted meetings with Korean technocrats in August 1997, when everyone had used the words "impending crisis." She said they all talked about the interconnections between the chaebol financing, the state of the banks, the exchange rate, and capital flows. There was no confusion about what the problems were, and there was a consensus that government would not act until forced to by a crisis. On Sachs's attempt to separate short-term issues from medium- and long-term issues, she said that, given the insolvency of the chaebol, dealing with the situation as if it were just a liquidity crisis would just postpone the crisis. Moving on to the current situations in the financial systems of crisis-affected countries (as of October 2000), Krueger said that the situation in Indonesia is very bad. The banking system is in bad shape because banks are holding nonnegotiable government bonds in the place of nonperforming loans. The problem with nonnegotiable bonds is that you can't lend them, so that there is no domestic credit, she said. Turning to Korea, she said that all is not well there either, with financial restructuring only half completed. She thinks Korea has gone too fast with its recovery without addressing fundamental weaknesses and would have been better off with a slower recovery that didn't leave another crisis looming for the future.

Responding to Krueger on the issue of timing, Sachs said that he was not making a distinction between what to do now and what to do ten years from now, but between now and three months or six months. Closing or suspending fourteen banks in Korea in December 1997, or closing sixteen Indonesian banks in the middle of an incipient run, is a gamble that does not make sense, he said. Responding to Nouriel Roubini's earlier observation about liquidity injections in Indonesia, Sachs said that it was not because the government was attempting to pump-prime the economy. They were responding to massive runs by depositors, and they had to decide whether to formally suspend the banking system - as was done in the United States in 1933 - or to provide liquidity.

Sachs said that Morris Goldstein might be right when he says the downturn was unavoidable, but he pointed out that no one was predicting at the time that the downturn was going to be -8 percent. Observing the contractionary policies that were being pursued, he said he believed at the time that the downturn would be very severe. He agreed that he is essentially calling for forbearance, but "not for years." Instead, he believes that you must pursue the policy course that does most to avoid a panic. Moreover, he said if Peter Garber is right, and it wasn't panic but rather the working of the value-at-risk models of the international commercial banks, then the situation is even worse, and suspensions of flows or other mechanisms for direct intervention become absolutely essential.

Remarking on the financial problems of the Korean chaebol, Sachs said that it is one thing for these groups to be going bankrupt, but it is something else for the economy to shrink by 7 percent. He said the financial and real 
sides are different for all sorts of reasons, and this explains why Korea was able to bounce back sharply, utilizing its capacity in some of the most important industries (e.g., semiconductors) in the world.

Fischer said he has little time for the charge that the IMF could have stemmed the capital outflows if it had expressed more confidence. He said he is more struck by the charge that the IMF "was asleep at the switch" and, with the possible exception of Thailand, never did get around to telling people that a disaster was coming. He thinks the Fund was late in Korea and missed some of the signals. However, he pointed out that the Koreans were hiding some of their reserves data. So, if anything, the Fund needs to answer to the charge that it was overly optimistic in its projections, not that it helped spread the panic.

On the issue of whether the output collapse could have been smaller, he said that an easier fiscal policy would have helped, but not substantially so. He also pointed out that the Mexican rescue went badly until there was a fiscal tightening. At the time, people criticized the IMF for not recognizing the contractionary impact of a tighter fiscal stance. However, there had to be a judgment on the relative sizes of Keynesian impact and the confidence impact, assuming these went in opposite directions. On dealing with the banking sector, he doesn't think forbearance is the right solution. A better solution would have been comprehensive guarantees, as happened in Thailand. It was important to get on with restructuring the banks as quickly as possible. The alternative model is Japan, which is what you get with very long forbearance, he said.

Regarding what was needed to restore confidence in Indonesia, Fischer said that no one was going to believe you were doing anything to solve the country's problems, unless you were seen to be doing something to solve the problems with the banks.

Finally, on the issue of IMF accountability, he noted that the heads of governments of leading industrial nations were closely involved in the Indonesian program, with many heads of government calling on Suharto to urge him to pursue the reforms. He stressed that IMF technocrats should not be making decisions that are at their core "political judgments," and he added that he feels immensely reassured that the Fund has to take its programs before its board and listen to what 182 governments think. It is essential that member governments support decisions. It is the IMF's job to get the technical side right, but "we cannot pretend that the technical things we do are purely technical and do not have political consequences," he said. 
